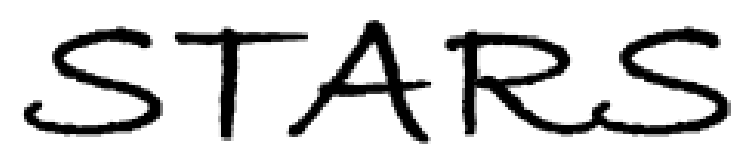

University of Central Florida

STARS

\title{
Using Cell Phone Technology For Self-monitoring Procedures In Inclusive Settings
}

\author{
Pena Bedesem \\ University of Central Florida
}

Part of the Education Commons

Find similar works at: https://stars.library.ucf.edu/etd

University of Central Florida Libraries http://library.ucf.edu

This Doctoral Dissertation (Open Access) is brought to you for free and open access by STARS. It has been accepted for inclusion in Electronic Theses and Dissertations, 2004-2019 by an authorized administrator of STARS. For more information, please contact STARS@ucf.edu.

\section{STARS Citation}

Bedesem, Pena, "Using Cell Phone Technology For Self-monitoring Procedures In Inclusive Settings" (2010). Electronic Theses and Dissertations, 2004-2019. 4236.

https://stars.library.ucf.edu/etd/4236

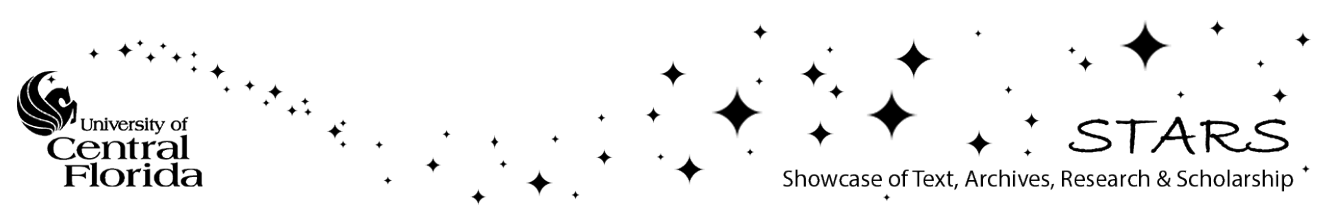




\title{
USING CELL PHONE TECHNOLOGY FOR SELF-MONITORING PROCEDURES IN INCLUSIVE SETTINGS
}

\author{
by
}

\section{PEÑA LASISTE BEDESEM}

B.S. University of Central Florida, 1998

M.A. University of Central Florida, 2002

A dissertation in partial fulfillment of the requirements

for the degree of Doctor of Philosophy

in the College of Education

at the University of Central Florida

Orlando, Florida

Summer Term

2010

Major Professors:

Lee Cross

Lisa Dieker

Wilfred Wienke

Eleazar Vasquez 
(C) 2010 Peña Lasiste Bedesem 


\begin{abstract}
The purpose of this study was to determine the effects and social validity of an innovative method for middle school students with high incidence disabilities to self-monitor their behavior in inclusive settings. Traditional self-monitoring procedures were updated by incorporating cell phone technology. The updated self-monitoring procedure, called CellF-Monitoring, used a cell phone to replace traditional cueing and recording procedures.

The study took place in an inclusive middle school classroom in central Florida with two students with high incidence disabilities. A multiple-baseline-across-participants single subject design was employed. Results indicate that the CellF-Monitoring procedure is an effective and socially valid intervention.
\end{abstract}

Although results of the study demonstrated the effectiveness of the CellF-Monitoring procedure, there are several limitations that should be discussed, including the number of replications, the sample size, teacher implementation, and use of personal cell phones. The limitations of the study provide several opportunities for future research. 
I dedicate this dissertation to my parents, John and Jocelyne Lasiste. I would not have made it this far without your unconditional love, support, spare bedroom, pet care, vehicle maintenance, home-cooked meals, and endless provision of Diet Mountain Dew throughout the years. I love you and appreciate all that you have done for me. 


\section{ACKNOWLEDGMENTS}

First, I thank my chair, Dr. Lee Cross, for her continuous support in the Ph.D. program. Dr. Cross was always there to listen, brainstorm, and give advice. She did not allow me to get overwhelmed or give up, especially when it seemed like I was never going to finish my dissertation research.

A special thanks goes to my mentor, Dr. Lisa Dieker, for frequently forcing me outside of my comfort zone. Dr. Dieker was always certain that I would succeed even when I was certain that I wouldn't and gave me just enough freedom to be proud of my accomplishments while providing a safety net just in case I needed it. Although I may have felt like I was out there on my own at times, looking back, I'm almost positive that she had your eye on me the entire time.

I would like to thank the rest of my committee: Dr. Wilfred Wienke, who took me under his wing and asked me the tough questions; Dr. Eleazar Vasquez, for making sure that I had a strong research design; and, Dr. Gulchak, who agreed to join my committee on short notice, found time to review my dissertation several times, and provided insightful feedback.

I cannot go any further without thanking my 'UCF Family': I would not have made it through the last three years without the support, encouragement, and humor of my cohort - Angel Lopez, Tanya Moorehead, Kimberly Pawling, and Wanda Wade. I can't even begin to express 
how much I appreciate each of you and how lucky I was to be a member of such an amazing group of people.

Let me also say 'thank you' to: Dr. Platt, Dr. Hopp, and the rest of the Holmes Scholars for their encouragement and unconditional acceptance; and Linda Alexander, for knowing everything and her willingness to share almost all of it!

I thank my sister, Juana, and her husband, Joey, for their continued support and encouragement and for making me laugh by constantly reminding me that I was over thirty and still living with my parents; my best friend, Jennifer White, for being the most supportive and understanding friend that I have ever had; and Brian Barber for giving me a place to escape to each weekend, keeping me grounded, helping me find my place in the field, and showing me that I can still be silly.

Last, but certainly not least, I want to extend my eternal gratitude to my late husband, Erik R. Bedesem, for his unwavering encouragement by citing one of his favorite poems by Langston Hughes: "Hold fast to dreams, for if dreams die life is a broken-winged bird that cannot fly. Hold fast to dreams, for when dreams go life is a barren field frozen with snow." 


\section{TABLE OF CONTENTS}

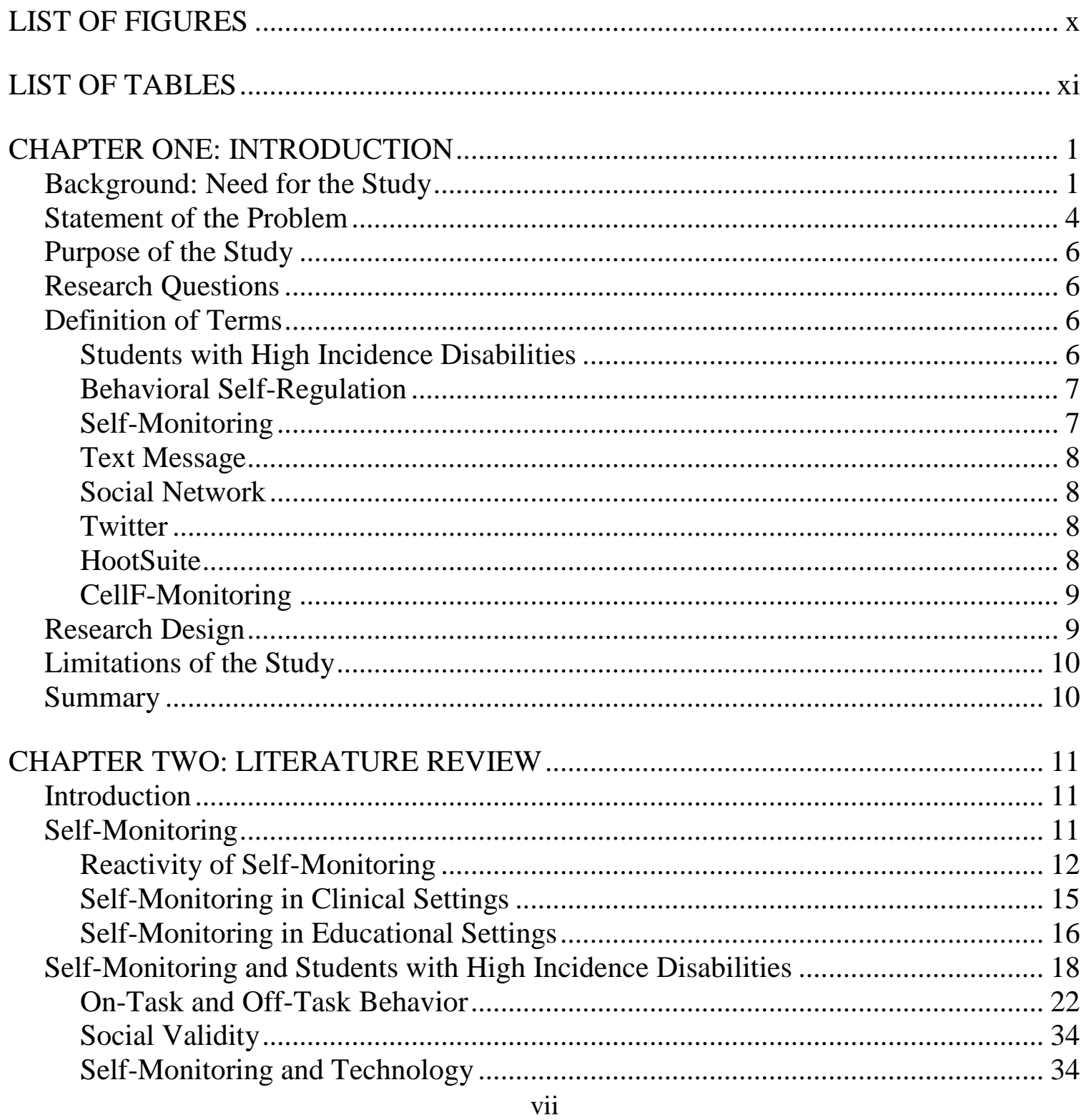




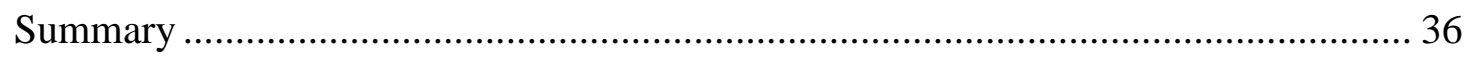

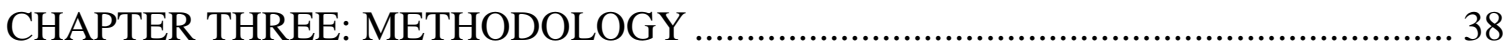

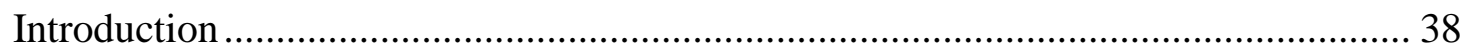

Purpose of the Study ......................................................................................... 38

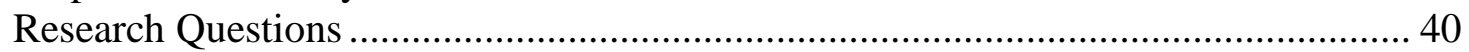

Ethical Considerations ....................................................................................... 40

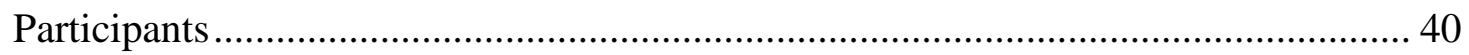

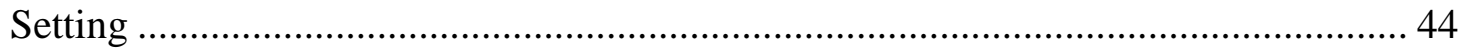

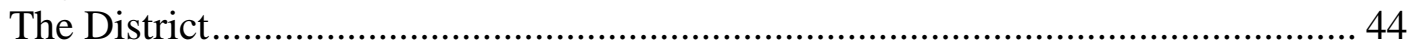

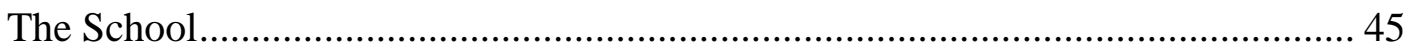

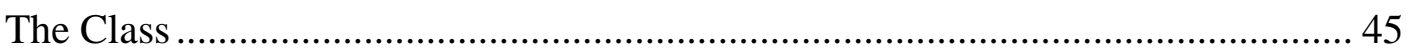

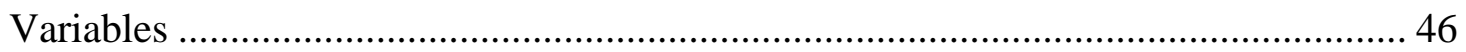

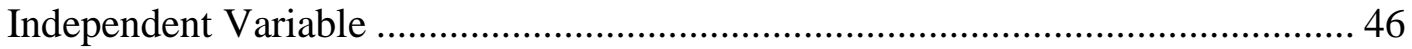

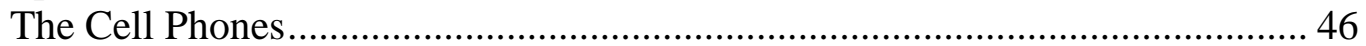

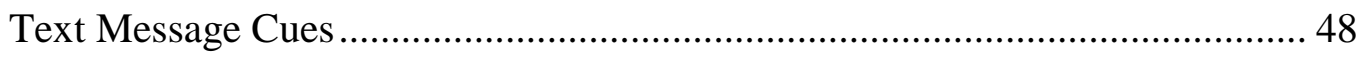

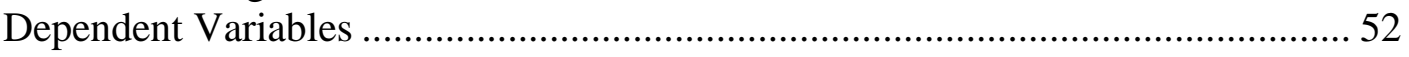

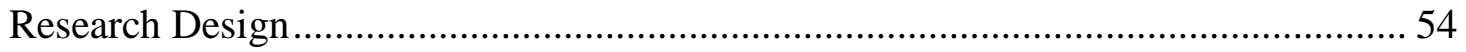

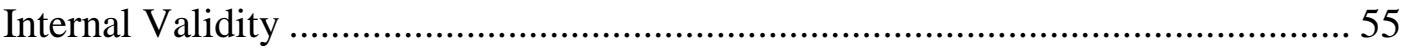

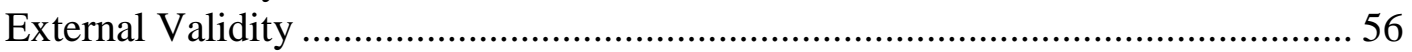

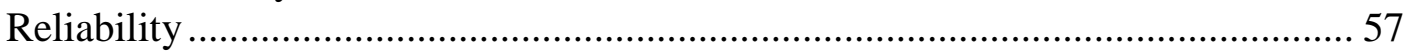

Inter-Observer Agreement......................................................................... 58

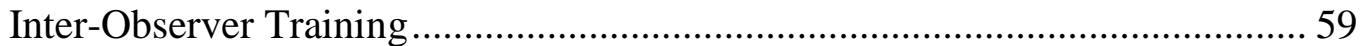

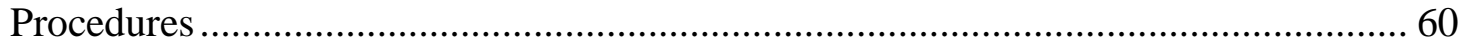

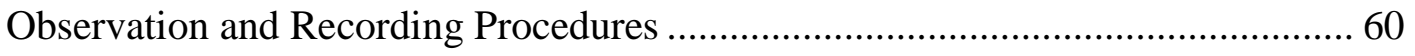

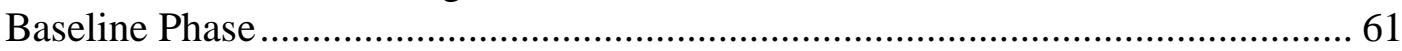

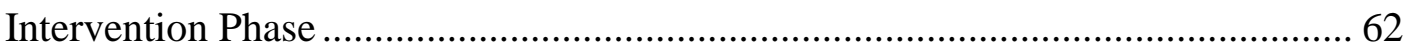

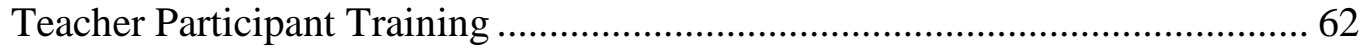

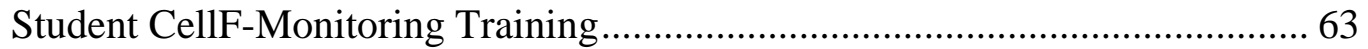

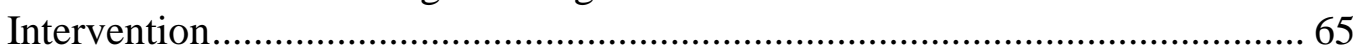

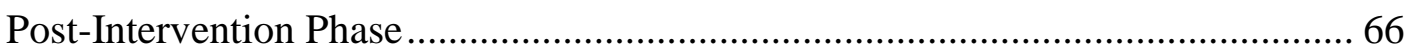

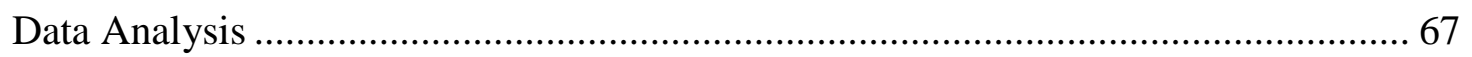

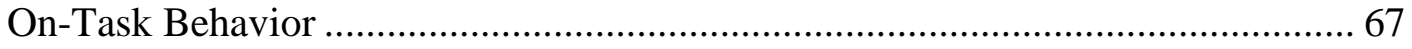

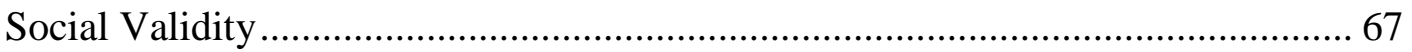

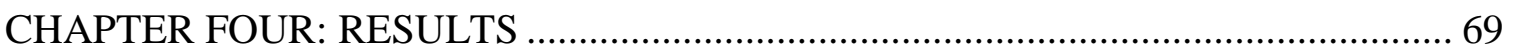

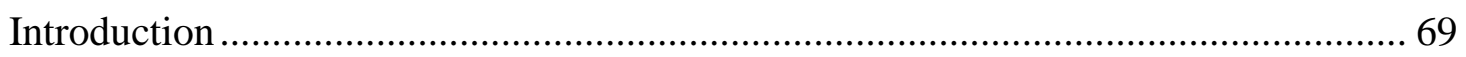

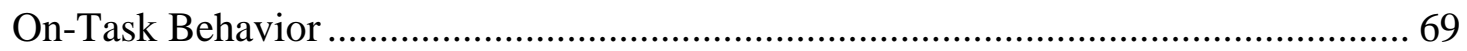

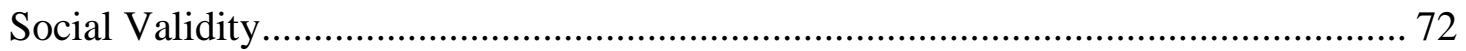

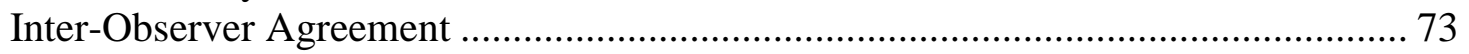




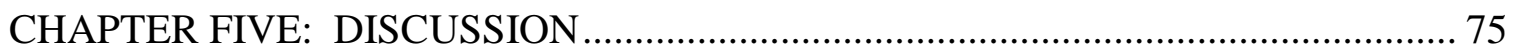

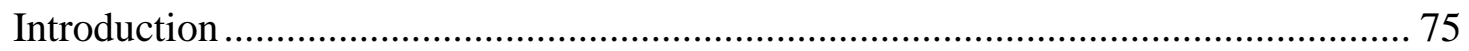

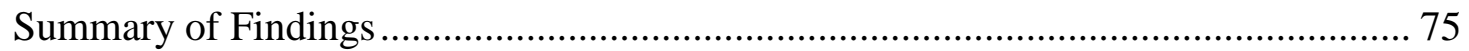

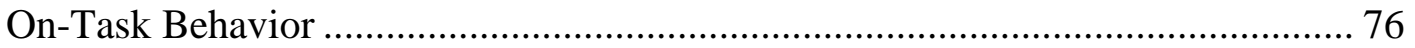

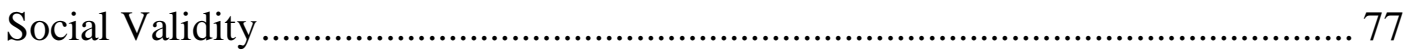

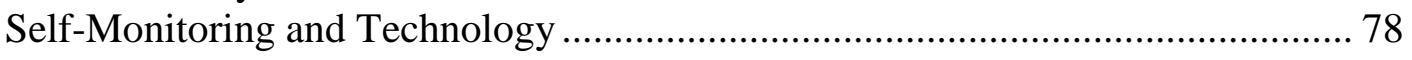

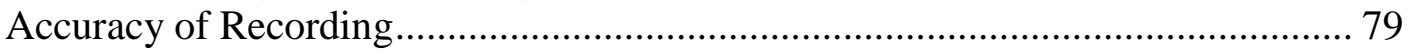

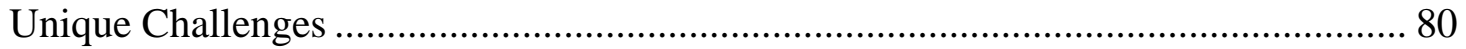

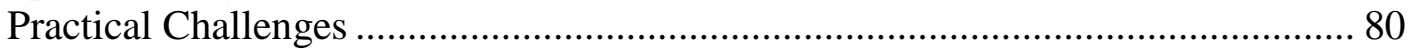

Technical Challenges ............................................................................................. 82

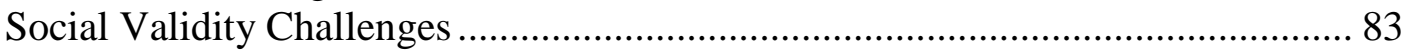

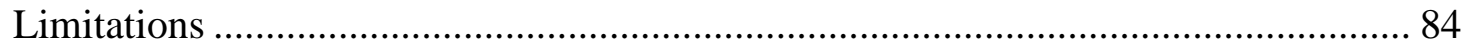

Suggestions for Future Research............................................................................ 86

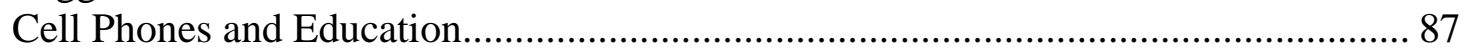

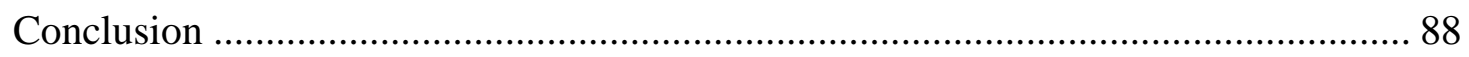

APPENDIX A INSTITUTIONAL REVIEW BOARD LETTER OF APPROVAL ........... 1

APPENDIX B TEACHER CONSENT DOCUMENT ...................................................... 3

APPENDIX C PARENT CONSENT DOCUMENT ……………………………........ 5

APPENDIX D SOCIAL VALIDITY QUESTIONNAIRES ............................................. 8

APPENDIX E OBSERVATION RECORDING SHEET …………………………...... 11

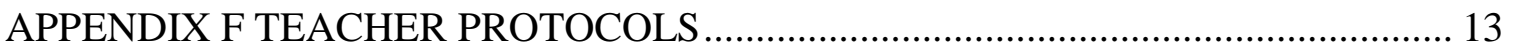

APPENDIX G CELLF-MONITORING TRAINING PRESENTATION ....................... 15

APPENDIX H CELLF-MONITORING TRAINING CHECKLIST ................................ 20

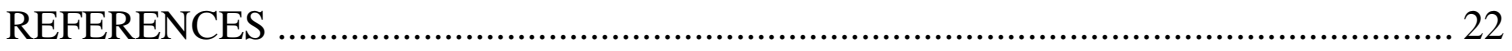




\section{LIST OF FIGURES}

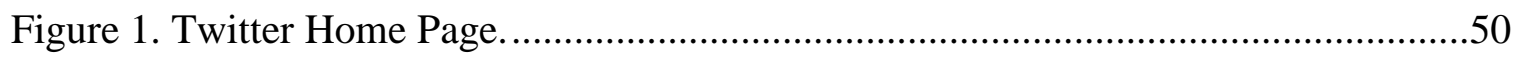

Figure 2. HootSuite Home Page. ......................................................................51

Figure 3. CellF-Monitoring Cueing Procedure .......................................................52

Figure 4. Three Steps to CellF-Monitoring..................................................................64

Figure 5. Observed On-Task Behavior. ................................................................ 70 


\section{LIST OF TABLES}

Table 1. Self-Monitoring Studies in Special and General Education Settings .................25

Table 2. Participant Characteristics ....................................................................43

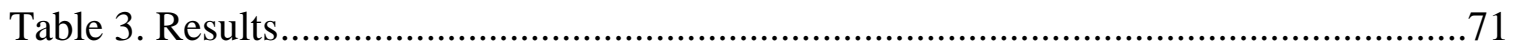




\title{
CHAPTER ONE: INTRODUCTION
}

\author{
Background: Need for the Study
}

The No Child Left Behind Act (NCLB; 2001) and the Individuals with Disabilities Act (IDEA; 2004) raised expectations for academic achievement for all students. As mandated by NCLB, states are required to (a) develop academic standards that are the same for all students, (b) ensure that all students participate in annual state assessments and make adequate yearly progress (AYP), and (c) ensure that there is a highly qualified teacher in each classroom (Cortiella, 2006; Rosenberg, Sindelar, \& Hardman, 2004). An outcome of NCLB is that all students, including those with disabilities, are to achieve higher levels of academic performance if schools developed the highest academic standards, provided a rigorous curriculum, and used scientifically-based instruction. If students do not achieve higher levels of academic performance, schools, districts, and states are held accountable for their students' failure (Hardman \& Dawson, 2008; Rosenberg, Sindelar, \& Hardman, 2004). However, if students with disabilities are required to participate in the same state and district assessments as their peers without disabilities, they need to have access to the curricula on which the assessments are based (Rosenberg, Sindelar, \& Hardman, 2004). This increased focus on access to the general education curriculum translated into a push for inclusion of students with disabilities (Kauffman, 
Bantz, \& McCullough, 2002). According to IDEA data, the number of students with disabilities who spent $80 \%$ or more of the school day in a general education classroom increased from 2,839,431 in 2001 to 3,191,458 in 2004 (Data Accountability Center, 2009). However, Congress was unsure if changing the educational placement of students with disabilities alone would generate the valued outcomes of employment, independence, and community involvement (Hardman \& Dawson, 2008; Rosenberg, Sindelar, \& Hardman, 2004). Therefore, the 2004 reauthorization of IDEA is designed to improve the outcomes of students with disabilities by ensuring that (a) students with disabilities have access to, are involved in, and progress in a challenging general education curriculum; and (b) that teachers are made accountable for student learning (Hardman \& Dawson, 2008; Rosenberg, Sindelar, \& Hardman, 2004).

Although placement in general education classrooms provides students with disabilities access to the same curricula and expectations as their peers without disabilities, many students with disabilities exhibit certain behavioral characteristics that may exacerbate academic deficits and impede their ability to function in a general education classroom (Shimabukuro, Prater, Jenkins, \& Edelen-Smith, 1999). Students across disability categories commonly demonstrate behaviors such as hyperactivity, inattentiveness, poor social skills, and spend less time on task (Rock, Fessler, \& Church, 1997; Truesdell \& Abramson, 1992); all of which can be attributed to an inability to self-regulate behavior (Harris, Friedlander, Saddler, Frizzelle, \& Graham, 2005; Shimabukuro, Prater, Jenkins, \& Edelen-Smith, 1999). 
A student's ability to self-regulate his or her own behavior begins with the ability to selfmonitor his or her own behavior (Kanfer \& Karoly, 1972). According to Polsgrove and Smith (2004), self-monitoring is a critical component in the self-regulation process because it represents a student's commitment to behavioral change. Self-monitoring has been defined as a student's ability to (1) accurately observe their own behavior, (2) recognize the current behavior as inadequate or inappropriate, and (3) identify the problematic behavior or behaviors (Kanfer \& Karoly, 1972); and as a two-stage procedure in which a student (1) observes his or her own behavior to determine whether a targeted behavior has occurred and then (2) records the occurrence of the targeted behavior (Nelson \& Hayes, 1981). Generally, self-monitoring procedures include three components: (1) a cue provided to the student, (2) the student assessing whether the targeted behavior has occurred, and (3) recording the occurrence or nonoccurrence of the targeted behavior (DiGangi, Maag, \& Rutherford, 1991; Glynn \& Thomas, 1974; Glynn, Thomas, \& Shee, 1973).

Self-monitoring, as an intervention, has shown positive results for students with and without disabilities across educational settings (Anderson \& Wheldall, 2004; Ballard \& Glynn, 1975; Crum, 2004; Fitzpatrick \& Knowlton, 2009; Glynn, Thomas, \& Shee, 1973; Gottman \& McFall, 1972; Gulchak, 2008; Hallahan, Lloyd, Kosiewicz, Kauffman, \& Graves, 1979; Hallahan, Marshall, \& Lloyd, 1981; Harris, Friedlander, Saddler, Frizzelle, \& Graham, 1994; Kern \& Dunlap, 1994; McDougall \& Brady, 1995; Mooney, Ryan, Uhing, Reid, \& Epstein, 2005; Ninness, Fuerst, Rutherford, \& Glenn, 1991). Benefits of self-monitoring in educational 
settings include increasing students' self-reliance, decreasing students' overreliance on external control agents, and increasing teacher instructional time by decreasing the amount of time spent on behavior management (McDougall, 1998). As such, self-monitoring has been highlighted as an effective intervention to increase students with disabilities' ability to function in general education settings (Dalton, Martella, \& Marchand-Martella, 1999; Harris, Friedlander, Saddler, Frizzelle, \& Graham, 2005; Prater, Joy, Chilman, Temple, \& Miller, 1991; Rooney, Hallahan, \& Lloyd, 1984).

\section{$\underline{\text { Statement of the Problem }}$}

Students with disabilities, especially those with high incidence disabilities, often lack the ability to regulate their own behavior making it difficult to function in general education classrooms. Students with high incidence disabilities who are unable to regulate their own behavior typically have a range of issues (Rock, Fessler, \& Church, 1997; Truesdell \& Abramson, 1992). Research has supported the use of self-monitoring as a strategy to teach students with disabilities to regulate their behavior and potentially "provide a mechanism for generalizing improvements in academic and behavioral performance over settings and across time" (Polsgrove \& Smith, 2004, p. 406).

Typically, self-monitoring procedures incorporate paper, pencil, a cassette tape player, and headphones, which may appear primitive and outdated to a generation that is highly mobile and immersed in technology on a daily basis. Students with disabilities often want to fit in with their nondisabled peers and run the risk of standing out if they use such overt and antiquated 
intervention procedures. It is unlikely that students will want to use, or benefit from, the selfmonitoring procedures if there is a possibility of any social repercussions resulting from its use. Thus, updated self-monitoring procedures are needed or the proven benefits of self-monitoring on students with high incidence disabilities will be wasted.

Cell phones have the potential to make self-monitoring, an established research-based intervention, more discreet, socially acceptable, and mobile. First, the text messaging function of a cell phone could replace outdated procedures traditionally used for two of the three components of self-monitoring, cueing and recording. Secondly, using a cell phone as the selfmonitoring device may also make self-monitoring procedures more socially acceptable to students with high incidence disabilities in inclusive classrooms. Lastly, cell phones could also improve the mobility of self-monitoring procedures for middle school students with high incidence disabilities in general education classrooms as they typically move from class to class throughout the school day.

Although cell phones could be a viable self-monitoring device, no studies were found that explore the use of cell phones to update traditional self-monitoring procedures. As such, the researcher updated the self-monitoring procedure using cell phone technology. The updated selfmonitoring procedure, CellF-Monitoring, used text messages to serve as cues to prompt selfassessment and replies to the text message cues to record the occurrence or nonoccurrence of targeted behavior. The text message cues replaced traditional cueing procedures that included a 
beeper tape, tape player, and headphones. The replies to the text message cues replaced traditional recording procedures that included paper and pencil.

\section{Purpose of the Study}

The broad purpose of this study was to explore the use of an innovative self-monitoring procedure on the on-task behavior of students with high incidence disabilities. Specifically, the study sought to determine (1) the effects of CellF-Monitoring, a self-monitoring procedure that utilized cell phone technology and (2) the social validity of the CellF-Monitoring procedure.

\section{Research Questions}

1. How will CellF-Monitoring, a self-monitoring procedure that utilizes a cell phone for cueing and recording, affect the on-task behavior of middle school students with high incidence disabilities in inclusive settings?

2. How will middle school general education teachers, middle school special education teachers, and middle school students with high incidence disabilities rate the social validity of the CellF-Monitoring procedure?

\section{$\underline{\text { Definition of Terms }}$}

Students with High Incidence Disabilities

Students with high incidence disabilities were defined for the purposes of this study as students with learning disabilities (LD) and students with emotional disturbance (ED) as defined by the Individuals with Disabilities Education Act (IDEA) of 2004; and students diagnosed with 
attention deficit-hyperactivity disorder (ADHD) who are eligible for special education and related services under Section 504 of the Rehabilitation Act of 1973 (Gresham \& MacMillan, 1997).

\section{Behavioral Self-Regulation}

Behavioral self-regulation refers to a complex process to ultimately achieve self-control (Kanfer \& Karoly, 1972; Mahoney \& Thoresen, 1972; Polsgrove \& Smith, 2004) that includes four stages (Kanfer \& Karoly, 1972; Polsgrove \& Smith, 2004): (1) Self-Monitoring, Discrepancy Detection, and Commitment to Change; (2) Goal Setting; (3) Strategy Selection and Implementation; and (4) Self-Evaluation and Self-Reinforcement. According to Polsgrove and Smith (2004), an individual is exercising behavioral self-regulation when he or she "acts independently of what one would predict based upon the immediately available external consequences and is more reliant (presumably) on internal controlling responses" (p. 402).

\section{Self-Monitoring}

For the purpose of this study, self-monitoring was defined as a procedure that includes three components: (1) a cue provided to the student, (2) the student assessing whether the targeted behavior has occurred, and (3) the student recording the occurrence or nonoccurrence of the targeted behavior. 


\section{Text Message}

A text message is a message with up to 140 characters that is composed using the keypad of a cell phone. Text messages are sent from the phone on which it was composed directly to another cell phone. Text messaging is not restricted by cell phone service carriers and can be sent to any cell phone.

\section{Social Network}

A social network is an association of people drawn together by family, work, interests, or hobbies. Social networking occurs over the internet through a variety of websites and applications that allow users to share content, interact, and develop communities around similar interests.

\section{Twitter}

Twitter is a social networking application where friends, family, and co-workers can communicate with the exchange of quick, frequent messages of 140 characters or less, called tweets (www.twitter.com).

HootSuite

HootSuite is a Professional Social Media Dashboard where individuals and companies can manage multiple social networking profiles and track followers ( $\underline{w w w . h o o t s u i t e . c o m})$. 


\section{CellF-Monitoring}

CellF-Monitoring is an updated self-monitoring procedure that incorporates the use of cell phones as the self-monitoring device. The CellF-Monitoring procedure utilized a cell phone to replace the cueing and recording procedures used in traditional self-monitoring procedures. In CellF-Monitoring, cues are sent as text messages to prompt self-assessment and recording is done by replying to the text message cue indicating the occurrence or nonoccurrence of the target behavior.

\section{$\underline{\text { Research Design }}$}

Single-subject research was employed for the purposes of this study. Single-subject research is (a) practical for evaluating behavioral interventions, (b) practical for evaluating behavioral interventions in typical classroom settings, and (c) cost-effective (Horner, Carr, Halle, McGee, Odom, \& Wolery, 2005). A multiple-baseline-across-participants design was employed to determine the effects of CellF-Monitoring on the on-task behavior of students with high incidence disabilities in inclusive settings. A multiple-baseline-across-participants design was chosen for the purposes of this study to demonstrate the effects of the intervention as an alternative to a reversal design to alleviate ethical concerns about withdrawing an effective intervention or that learned behavior cannot be unlearned (Baer, Wolf, \& Risley, 1968; Kazdin, 1982; Tankersley, Harijusola-Webb, \& Landrum, 2008; Tawney \& Gast, 1984). Additionally, a researcher-developed questionnaire was used to determine the practicality of the CellFMonitoring procedures. 


\section{Limitations of the Study}

There are several limitations to the study. Only two students participated in the study. The small sample size limits generalization and external validity. A second limitation of the current study is that the classroom teacher was not involved in the training or implementation of the intervention. Finally, the student participants used cell phones that were provided by the researcher instead of using their personal cell phones.

\section{Summary}

This research study was grounded on literature on behavioral self-regulation deficits typically demonstrated by students with high incidence disabilities (Harris, Friedlander, Saddler, Frizzelle, \& Graham, 1994; Mayer, Lochman, \& Van Acker, 2005; Polsgrove \& Smith, 2004; Robinson, Smith, Miller, \& Brownell, 1999; Rock, Fessler, \& Church, 1997), reports of the positive effects of self-monitoring as the first step for students with high incidence disabilities to regulate their behavior across settings (Anderson \& Wheldall, 2004; Crum, 2004; Fitzpatrick \& Knowlton, 2009; Gulchak, 2008; Harris, Friedlander, Saddler, Frizzelle, \& Graham, 1994; Kern \& Dunlap, 1994; McDougall \& Brady, 1995; Mooney, Ryan, Uhing, Reid, \& Epstein, 2005; Polsgrove \& Smith, 2004; Ninness, Fuerst, Rutherford, \& Glenn, 1991), and the need to make self-monitoring procedures more conducive to and socially acceptable in inclusive settings. The following chapter provides a review of the literature pertaining to the use of self-monitoring with students with high incidence disabilities in educational settings. 


\title{
CHAPTER TWO: LITERATURE REVIEW
}

\author{
$\underline{\text { Introduction }}$
}

The purpose of this chapter is to provide a review of the literature pertinent to the research study. The chapter begins with a brief historical overview of self-monitoring followed by a brief description of traditional self-monitoring procedures in clinical and educational settings. Next, the author presents evidence to support the use of self-monitoring as an intervention for students with high incidence disabilities. Finally, the author closes the chapter by providing supporting evidence for the use of cell phone technology to enhance and make selfmonitoring procedures more practical for students with disabilities in inclusive settings.

\section{Self-Monitoring}

Self-monitoring is a component of a complex four-stage self-regulation process to ultimately achieve behavioral self-control (Kanfer \& Karoly, 1972; see Polsgrove \& Smith, 2004 for discussion). The first stage, self-monitoring, involves accurately observing one's own behavior, recognizing current behavior as inadequate or inappropriate, and identifying the behavior that is problematic. The second stage, goal-setting, comprises recognizing behavior that is required in the current situation. The third stage, strategy selection and implementation, includes selecting and implementing a set of strategies to effectively regulate behavior. The 
fourth stage, self-evaluation and self-reinforcement, concerns objectively evaluating performance and altering for the current situation. Self-monitoring is a critical component in the selfregulation process because, as the first stage, it represents the student's commitment to behavioral change (Polsgrove \& Smith, 2004). Self-monitoring is a procedure that entails two stages in which an individual (1) observes his or her own behavior to determine if a targeted behavior has occurred and (2) records the occurrence of the observed behavior (Nelson \& Hayes, 1981). Generally, self-monitoring procedures include three components: (1) a cue provided to the student, (2) the student assessing whether the targeted behavior has occurred, and (3) recording the occurrence or nonoccurrence of the targeted behavior (DiGangi, Maag, \& Rutherford, 1991; Glynn \& Thomas, 1974; Glynn, Thomas, \& Shee, 1973).Self-monitoring has been used successfully in clinical (Korotitsch \& Nelson-Gray, 1999) and educational settings (McDougall, 1998; McLaughlin, 1976; O’Leary \& Dubey, 1979; Reid, 1996; Rosenbaum \& Drabman, 1979).

\section{Reactivity of Self-Monitoring}

The effectiveness of self-monitoring to increase desired behaviors is attributed to its reactive effects on targeted behaviors (Anderson \& Wheldall, 2004; Broden, Hall, \& Mitts, 1971; Cavalier, Ferretti, \& Hodges, 1997; DiGangi, Maag, \& Rutherford, 1991; Gottman \& McFall, 1972; Hayes \& Nelson, 1983; Kirby, Fowler, \& Baer, 1991; Korotitsch \& Nelson-Gray, 1999; Lipinski, Black, Nelson, \& Ciminero, 1975; McLaughlin, 1976; Nelson \& Hayes, 1981; Snider, 1983). Reactivity is defined as the effect that self-monitoring has on the frequency of targeted 
behavior as a function of the self-monitoring procedure (Kanfer, 1970; Nelson \& Hayes, 1981; Rachlin, 1974). In other words, the act of one self-monitoring his or her behavior influences the frequency of the monitored behavior.

Three theories are often used to explain the reactivity of self-monitoring (Anderson \& Wheldall, 2004; Korotitsch \& Nelson-Gray, 1999; Nelson \& Hayes, 1981; Snider, 1987). The first theory explaining the reactivity of self-monitoring is the cognitive-behavioral theory. The cognitive-behavioral model includes an internal self-evaluative process in which covert selfstatements are seen as the overt behavior change agents (Kanfer, 1970; Korotitsch \& NelsonGray; 1999; Nelson \& Hayes, 1981; Snider, 1987). The second theory explaining the reactivity of self-monitoring is the operant model. According to the operant theory of reactivity, selfmonitoring serves as a cue to environmental consequences and the consequences are the behavior change agents (Korotitsch \& Nelson-Gray, 1999; Nelson \& Hayes, 1981; Rachlin, 1974; Snider, 1987). The third, and final, theory explaining the reactive effects of selfmonitoring is Nelson and Hayes' (1981) extension of the operant theory of reactivity. Nelson and Hayes assert that the entire self-monitoring procedure affects the reactivity of selfmonitoring. The self-monitoring procedures, including the devices, function in a manner similar to external cues in changing behavior. For example, reactive effects could be produced even when self-recording is inaccurate or when self-monitored behavior is at a low rate because the self-recording device itself produces the reactive effects. 
Several researchers have conducted studies to gain a better understanding of the reactive effects of self-monitoring. For instance, Lipinski, Black, Nelson, and Ciminero (1975) investigated variables that could enhance the functions of self-monitoring by differentially reinforcing the reactive effects of self-monitoring or the accuracy of recording. Participants were 20 postsecondary students who displayed high frequencies of face-touching who were nested in the two treatment groups. The results indicated that the self-monitoring procedures produced reactive effects without accuracy of recording. Participants who were reinforced for accuracy of recording increased their accuracy but did not decrease the frequency of the targeted behavior. However, participants who were reinforced for decreasing the frequency of the targeted behavior demonstrated a decrease in the behavior without increasing their recording accuracy. The researchers' findings support Nelson and Hayes' (1981) later theory that the procedure and devices used to self-monitor can positively influence behavior regardless of recording accuracy.

Hayes and Nelson (1983) evaluated the functional equivalence of self-monitoring and external cues on the frequency of face-touching with sixty postsecondary students. Baseline data were collected on the frequency of face-touching for all participants followed by random assignment of each participant to one of four groups: (1) control, (2) self-monitoring, (3) contingent external cuing, or (4) noncontingent external cuing group. The control group was only asked to watch a movie on autism while participants in the self-monitoring group were asked to watch the movie and touch a telegraph key each time they touched their face. The contingent external cuing group was asked to watch the movie and tough a telegraph key each 
time the message "don't touch your face" flashed on the screen. The participants did not know that the observer would flash the message each time the participant touched her face. The last group, noncontingent external cuing group, was asked to watch the message and touch the telegraph key each time the message "don't touch your face" flashed on the screen, which was based on a fixed interval. Results indicated that the external cuing (contingent and noncontingent) produced reactive effects indistinguishable from self-monitoring supporting Nelson and Hayes' theory that self-monitoring procedures function in a manner similar to external cues.

\section{Self-Monitoring in Clinical Settings}

Self-monitoring has a substantial history in the research literature as an assessment tool in clinical practice (Korotitsch \& Nelson-Gray, 1999). The role of self-monitoring for assessing behavior is of great import to behavior therapists within clinical assessment (Anderson \& Wheldall, 2004; Korotitsch \& Nelson-Gray, 1999; Nelson \& Hayes, 1981) because 'accurate assessment of responses and their controlling variables is a cornerstone of behavior therapy' (Korotitsch \& Nelson-Gray, 1999, p. 415). Elliot, Miltenberger, Kaster-Bundgaard, \& Lumley (1996) reported on a survey indicating that $83 \%$ of practitioners in the field of behavior therapy reported using self-monitoring procedures with $44 \%$ of their clients (as cited in Korotitsch \& Nelson-Gray, 1999, p. 415). According to Korotitsch and Nelson-Gray (1999), the use of selfmonitoring as an assessment tool is perpetuated for several reasons. To begin with, selfmonitoring requires minimal clinical resources and, therefore, provides an inexpensive 
alternative for data collection. Also, self-monitoring allows clients to collect data on behaviors, such as covert or personal behaviors that preclude the use of direct observation. Finally, selfmonitoring can be used in all stages of assessment, including diagnosis and treatment selection; and conducting a functional assessment and evaluating treatment outcomes. As the use of selfmonitoring as an assessment tool increased, clinicians realized that self-monitoring caused reactive changes in behavior that may be beneficial in educational settings (Reid, 1996).

\section{Self-Monitoring in Educational Settings}

As self-monitoring continued to show positive effects in changing behavior in clinical settings, educational researchers began to consider the potential benefits of self-monitoring in educational settings (McDougall, 1998; McLaughlin, 1976; O’Leary \& Dubey, 1979; Reid, 1996; Rosenbaum \& Drabman, 1979). Two seminal studies conducted by Broden, Hall, and Mitts (1971) explored the reactivity of self-recording on two students in general education settings. The first study examined the impact of self-recording on study behaviors and the second study assessed the impact of self-recording on the occurrences of talk-outs. The participant in the first study increased desired study behavior from $30 \%$ to $78 \%$. Additionally, when the self-recording sheets were withheld from the participant, study behavior dropped to an average of $27 \%$ and then increased again to an average of $80 \%$ when the recording sheets were reinstated. Results for the second study were not as favorable showing only an initial decrease in undesired talk-outs. Although the results of the two studies are mixed, they both support several theories reported in the researcher literature. First, the participant's decrease of desired behavior 
when the recording sheets were withdrawn and subsequent increase when they were reinstated supports Nelson and Hayes' (1981) assertion that the recording device itself is enough to produce changes in behavior. Second, the brief decrease of the participant's undesired behavior and sustained increase of the participant's desired behavior support the theory that the valence, or directionality, of the behavior influences the effects of self-monitoring (Reid, 1996). Selfmonitoring has shown to be more effective when attempting to increase a positive, or desired, behavior as opposed decreasing a negative, or undesirable, behavior (Gottman \& McFall, 1972; Korotitsch \& Nelson-Gray, 1999). Third, the participant in the first study was motivated to increase desired behavior whereas the participant in the second study did not express any motivation to decrease undesired behavior, which supports the theory that motivation is an essential component of self-monitoring. Prior research has indicated that the effectiveness of self-monitoring is predicated on the individual's motivation and commitment to behavior change (Anderson \& Wheldall, 2004; Kanfer \& Karoly, 1972; Korotitsch \& Nelson-Gray, 1999; Lipinski, Black, Nelson, \& Ciminero, 1975; O’Leary \& Dubey, 1979; Polsgrove \& Smith, 2004). Overall, the results established that self-monitoring could be used as a stand-alone intervention for promoting positive changes in behavior warranting further research of self-monitoring in educational settings. Subsequent studies broadened the self-monitoring research by demonstrating that self-monitoring has produced positive effects on academic performance (Ballard \& Glynn, 1975; Bahr, Fuchs, Fuchs, Fernstrom \& Stecker, 1993; Wood, Murdock, Cronin, Dawson, \& Kirby, 1998), on-task behavior (Ballard \& Glynn, 1975; Glynn \& Thomas, 
1974; Glynn, Thomas, \& Shee, 1973; Wood, Murdock, \& Cronin, 2002; Wood, Murdock, Cronin, Dawson, \& Kirby, 1998), classroom behavior and social skills (Peterson, Young, West, \& Peterson, 1999), and generalizing treatment gains across settings (Peterson, Young, West, \& Peterson, 1999; Wood, Murdock, \& Cronin, 2002).

\section{$\underline{\text { Self-Monitoring and Students with High Incidence Disabilities }}$}

Extensive research has also been conducted on the use of self-monitoring procedures as an intervention for students with high incidence disabilities (Anderson \& Wheldall, 2004; McDougall, 1998; Mooney, Ryan, Uhing, Reid, \& Epstein, 2005; Reid, 1996; Snider, 1987). Findings support the use of self-monitoring to increase desirable behaviors of students with high incidence disabilities (Anderson \& Wheldall, 2004; McDougall, 1998; Mooney, Ryan, Uhing, Reid, \& Epstein, 2005; Reid, 1996; Snider, 1987). As illustrated in Table 1, there is evidence to suggest that the effectiveness of self-monitoring is not determined by students' disability category, grade level, or educational setting. For example, eight studies focused on students with learning disabilities (Cavalier, Ferretti, \& Hodges, 1997; Dalton, Martella, \& MarchandMartella, 1999; DiGangi, Maag, \& Rutherford, 1991; Hallahan, Lloyd, Kosiewicz, Kauffman, \& Graves, 1979; Hallahan, Marshall, \& Lloyd, 1981; Lloyd, Hallahan, Kosiewicz, \& Kneedler, 1982; Rooney, Hallahan, \& Lloyd, 1984; Wolfe, Heron, \& Goddard, 2000), six on students with emotional disturbance (Crum, 2004; Dunlap, Clarke, Jackson, Wright, Ramos, \& Brinson, 1995; Kern \& Dunlap, 1994; Gulchak, 2008; McDougall \& Brady, 1995; Ninness, Fuerst, Rutherford, \& Glenn, 1991), one on students with attention deficit-hyperactivity disorder (Harris, 
Friedlander, Saddler, Frizzelle, \& Graham, 2005), and six studies that included participants from more than one disability category or participants with multiple disabilities (Mathes \& Bender, 1997; Prater, Joy, Chilman, Temple, \& Miller, 1991; Rock, 2005; Shapiro, DuPaul, \& BradlyKlug, 1998; Shimabukuro, Prater, Jenkins, \& Edelen-Smith, 1999; Smith \& Young, 1992). Additionally, 14 studies focused on students in elementary school (Crum, 2004; DiGangi, Maag, \& Rutherford, 1991; Dunlap, Clarke, Jackson, Wright, Ramos, \& Brinson, 1995; Kern \& Dunlap, 1994; Gulchak, 2008; Hallahan, Lloyd, Kosiewicz, Kauffman, \& Graves, 1979; Hallahan, Marshall, \& Lloyd, 1981; Harris, Friedlander, Saddler, Frizzelle, \& Graham, 2005; Lloyd, Hallahan, Kosiewicz, \& Kneedler, 1982; Mathes \& Bender, 1997; McDougall \& Brady, 1995; Rock, 2005; Rooney, Hallahan, Lloyd, 1984; Wolfe, Heron, \& Goddard, 2000), five in middle school (Cavalier, Ferretti, \& Hodges, 1997; Dalton, Martella, \& Marchand-Martella, 1999; Ninness, Fuerst, Rutherford, \& Glenn, 1991; Shapiro, DuPaul, \& Bradley-Klug, 1998; Shimabukuro, Prater, Jenkins, \& Edelen-Smith, 1999), and two in high school (Prater, Joy, Chilman, Temple, \& Miller, 1991; Smith \& Young, 1992; ). Eleven of the studies were conducted in self-contained settings (Cavalier, Ferretti, \& Hodges, 1997; Dunlap, Clarke, Jackson, Wright, Ramos, \& Brinson, 1995; Kern \& Dunlap, 1994; Gulchak, 2008; Hallahan, Lloyd, Kosiewicz, Kauffman, \& Graves, 1979; Hallahan, Marshall, \& Lloyd, 1981; Lloyd, Hallahan, Kosiewicz, \& Kneedler, 1982; McDougall \& Brady, 1995; Ninness, Fuerst, Rutherford, \& Glenn, 1991; Shapiro, DuPaul, \& Bradley-Klug, 1998; Shimabukuro, Prater, Jenkins, \& Edelen-Smith, 1999), two in resource room settings (Mathes \& Bender, 1997; Wolfe, 
Heron, \& Goddard, 2000), six in general education settings (Crum, 2004; Dalton, Martella, \& Marchand-Martella, 1999; DiGangi, Maag, \& Rutherford, 1991; Harris, Friedlander, Saddler, Frizzelle, \& Graham, 2005; Rock, 2005; Rooney, Hallahan, \& Lloyd, 1984), and three in multiple settings (Prater, Joy, Chilman, Temple, \& Miller, 1991; Shapiro, DuPaul, \& BradleyKlug, 1998; Smith \& Young, 1992). Not only has self-monitoring produced positive effects across disability categories, grade levels, and educational it has also produced positive effects across behaviors that are typically problematic for students with high incidence disabilities (Harris, Friedlander, Saddler, Frizzelle, \& Graham, 2005; Shimabukuro, Prater, Jenkins, \& Edelen-Smith, 1999).

The effectiveness of self-monitoring on academic performance and accuracy has been examined in special education settings (Hallahan, Lloyd, Kosiewicz, Kauffman, \& Graves, 1979; McDougall \& Brady, 1995) and general education settings (Harris, Friedlander, Saddler, Frizzelle, \& Graham, 2005). Academic behavior has been defined in terms of the rate of academic responses (Hallahan, Lloyd, Kosiewicz, Kauffman, \& Graves, 1979), total number of words written correctly (Harris, Friedlander, Saddler, Frizzelle, \& Graham, 2005), the percent of words spelled correctly (McDougall \& Brady, 1995), the total number of math problems completed and the total number of math problems that were correct (Rock, 2005), the percent of seat work correct and the percent of seat work complete (Smith \& Young, 1992). Many researchers have attributed increases in desired academic behavior to self-monitoring procedures (Hallahan, Lloyd, Kosiewicz, Kauffman, \& Graves, 1979; Harris, Friedlander, Saddler, Frizzelle, 
\& Graham, 2005; McDougall \& Brady, 1995; Smith \& Young, 1992). However, results from studies conducted by Rock (2005) and Wolfe, Heron, and Goddard (2000) were not consistent with previous findings. Rock (2005) evaluated the effectiveness of a self-monitoring intervention on students with different academic and behavioral needs in a general education classroom. Rock found that the self-monitoring intervention effectively increased the total number of math problems completed but not the number of math problems that were correct. Wolfe, Heron, and Goddard (2000) concluded that the effects of self-monitoring on the academic performance of students with LD in a special education resource classroom were not significant enough to declare a functional relationship.

In addition to increasing desired academic behaviors, researchers within the field of special education suggest that self-monitoring influences disruptive behavior, socially inappropriate behavior, and problem behavior in positive directions (Cavalier, Ferretti, \& Hodges, 1997; Dunlap, Clarke, Jackson, Wright, Ramos, \& Brinson, 1995; Kern \& Dunlap, 1994; Ninness, Fuerst, Rutherford, \& Glenn, 1991; Rock, 2005). Studies have indicated that self-monitoring effectively decreases disruptive and socially inappropriate behavior in special education settings (Cavalier, Ferretti, \& Hodges, 1997; Dunlap et al., 1995; Kern \& Dunlap, 1994; Ninness, Fuerst, Rutherford, \& Glenn, 1991); and problem behavior in general education settings (Rock, 2005). Though findings from such studies do not support the theory that selfmonitoring is more effective in increasing a behavior with a positive valence, or desirable 
behavior, than it is in decreasing a behavior with a negative valence, or undesirable behavior (Gottman \& McFall, 1972; Korotitsch \& Nelson-Gray, 1999; Reid, 1996).

\section{On-Task and Off-Task Behavior}

On-task behavior is the most frequently assessed dependent variable in self-monitoring studies involving students with high incidence disabilities across settings (Anderson \& Wheldall, 2004; Reid, 1996). As outlined in Table 1, self-monitoring effectively increases the on-task behavior of students across disability categories and grade levels in special and general education settings. Self-monitoring has effectively increased levels of on-task behavior for elementary and secondary students with high incidence disabilities in special education settings (Dunlap, Clarke, Jackson, Wright, Ramos, \& Brinson, 1995; Kern \& Dunlap, 1994; Gulchak, 2008; Hallahan, Lloyd, Kosiewicz, Kauffman, \& Graves, 1979; Hallahan, Marshall, \& Lloyd, 1981; Mathes \& Bender, 1997; McDougall \& Brady, 1995; Prater, Joy, Chilman, Temple, \& Miller, 1991; Shapiro, DuPaul, \& Bradley-Klug, 1998; Wolfe, Heron, \& Goddard, 2000) and general education settings (Crum, 2004; DiGangi, Maag, \& Rutherford, 1991; Harris, Friedlander, Saddler, Frizzelle, \& Graham, 2005; Rock, 2005; Rooney, Hallahan, \& Lloyd, 1984).

In addition to producing positive effects on on-task behavior in special education settings and general education settings, self-monitoring has increased levels of on-task behavior across multiple special education settings (Prater, Joy, Chilman, Temple, \& Miller, 1991; Shimabukuro, Prater, Jenkins, \& Edelen-Smith, 1999) and mutlitple general education settings (Prater, Joy, Chilman, Temple, \& Miller, 1991). For instance, self-monitoring increased the on-task behavior 
of a high school student with a comorbid diagnosis of emotional disturbance and a learning disability in resource government and English classes (Prater, Joy, Chilman, Temple, \& Miller, 1991). Similar results were reported by Shimabukuro, Prater, Jenkins, and Edelen-Smith (1999) who evaluated the effects of self-monitoring on the on-task behavior of middle school students with comorbid diagnoses of learning disabilities and attention deficit-hyperactivity disorder. Data indicate that the levels of on-task behavior increased for all participants across three content areas in a single self-contained classroom. However, results from a study conducted across two general education settings (Prater, Joy, Chilman, Temple, \& Miller, 1991) were not as favorable. Prater, Joy, Chilman, Temple, and Miller (1991) examined the effects of self-monitoring on the on-task behavior of a middle school student with a learning disability across general education study hall and social studies classes. During baseline, the participant's on-task mean for study hall was $50 \%$ and $66 \%$ for social studies. The participant's on-task mean increased to $89 \%$ in study hall but decreased to $59 \%$ in social studies during the intervention phase. The researchers attributed the decrease of the participant's on-task behavior from the baseline to intervention phase in social studies on an inadequately defined target behavior. The researchers claimed that it was difficult to establish a definition for on-task behavior that was appropriate for the setting and nature of the content area.

Researchers have also evaluated the generalizability of treatment gains produced by selfmonitoring but have not reported the same positive results found in previous research. For example, Ninness, Fuerst, Rutherford, and Glenn (1991) found that treatment gains produced by 
self-monitoring procedures did not transfer outside of the training setting. Middle school students with emotional disturbances were taught to self-monitor their off-task and socially inappropriate behavior in a self-contained classroom. Direct observation revealed a decrease in levels of off-task and socially inappropriate behavior in the self-contained setting. Treatment gains made in the training setting did not transfer outside of the treatment setting. The researchers reported that although off-task and socially inappropriate behavior did not transfer outside of the treatment setting, they continued to decrease in the treatment setting. The following year, Smith and Young (1992) found similar results when they examined the generalizability of treatment gains from the training setting to a general education classroom. Their study involved eight high school students with either a learning disability or an emotional disturbance who shared one general education English class. Data revealed that although participants' off-task behavior decreased in the training setting (special education classroom), treatment gains did not generalize to the general education English classroom. 
Table 1. Self-Monitoring Studies in Special and General Education Settings

\begin{tabular}{|c|c|c|c|c|c|c|}
\hline Study & $\begin{array}{l}\text { Research } \\
\text { Question }\end{array}$ & $\begin{array}{l}\text { Disability } \\
\text { Category of } \\
\text { Participants }\end{array}$ & Grade Level & Setting & $\begin{array}{l}\text { Dependent } \\
\text { Variable }\end{array}$ & Results \\
\hline \multirow{2}{*}{$\begin{array}{l}\text { Cavalier, } \\
\text { Ferretti, \& } \\
\text { Hodges, } 1997\end{array}$} & \multirow{2}{*}{$\begin{array}{l}\text { Evaluate effects } \\
\text { SR with } \\
\text { reinforcement }\end{array}$} & \multirow[t]{2}{*}{ LD } & \multirow[t]{2}{*}{ Middle School } & \multirow[t]{2}{*}{ Self-Contained } & $\begin{array}{l}\text { Inappropriate } \\
\text { vocalizations }\end{array}$ & Decreased \\
\hline & & & & & $\begin{array}{l}\text { Accuracy of } \\
\text { recording }\end{array}$ & $\begin{array}{l}\text { Low levels of } \\
\text { recording } \\
\text { accuracy }\end{array}$ \\
\hline Crum, 2004 & $\begin{array}{l}\text { Determine the } \\
\text { efficiency of } \\
\text { SM. }\end{array}$ & ED & $\begin{array}{l}\text { Elementary } \\
\text { School }\end{array}$ & $\begin{array}{l}\text { General } \\
\text { Education }\end{array}$ & $\begin{array}{l}\text { On-task } \\
\text { behavior }\end{array}$ & Increased \\
\hline \multirow[t]{2}{*}{$\begin{array}{l}\text { Dalton, Martella, } \\
\& \text { Marchand- } \\
\text { Martella, } 1999\end{array}$} & \multirow[t]{2}{*}{$\begin{array}{l}\text { Determine the } \\
\text { effects of a self- } \\
\text { management } \\
\text { program. }\end{array}$} & \multirow[t]{2}{*}{ LD } & \multirow[t]{2}{*}{ Middle School } & \multirow[t]{2}{*}{$\begin{array}{l}\text { General } \\
\text { Education }\end{array}$} & $\begin{array}{l}\text { Off-task } \\
\text { behavior }\end{array}$ & $\begin{array}{l}\text { Decreased off- } \\
\text { task behavior } \\
\text { with little } \\
\text { teacher } \\
\text { involvement }\end{array}$ \\
\hline & & & & & $\begin{array}{l}\text { Teacher ratings } \\
\text { of student } \\
\text { behavior }\end{array}$ & $\begin{array}{l}\text { Teachers } \\
\text { reported } \\
\text { decrease in off- } \\
\text { task behavior } \\
\text { and increase in } \\
\text { academic } \\
\text { performance and } \\
\text { productivity }\end{array}$ \\
\hline
\end{tabular}




\begin{tabular}{|c|c|c|c|c|c|c|}
\hline Study & $\begin{array}{l}\text { Research } \\
\text { Question }\end{array}$ & $\begin{array}{l}\text { Disability } \\
\text { Category of } \\
\text { Participants }\end{array}$ & Grade Level & Setting & $\begin{array}{l}\text { Dependent } \\
\text { Variable }\end{array}$ & Results \\
\hline \multirow{2}{*}{$\begin{array}{l}\text { DiGangi, Maag, } \\
\text { \& Rutherford, } \\
1991\end{array}$} & \multirow{2}{*}{$\begin{array}{l}\text { Investigate the } \\
\text { effects of self- } \\
\text { graphing on } \\
\text { improving the } \\
\text { reactivity of SM } \\
\text { procedures. }\end{array}$} & \multirow[t]{2}{*}{ LD } & \multirow[t]{2}{*}{$\begin{array}{l}\text { Elementary } \\
\text { School }\end{array}$} & \multirow[t]{2}{*}{$\begin{array}{l}\text { General } \\
\text { Education }\end{array}$} & $\begin{array}{l}\text { On-task } \\
\text { behavior }\end{array}$ & Increased \\
\hline & & & & & $\begin{array}{l}\text { Academic } \\
\text { performance }\end{array}$ & Increased \\
\hline \multirow[t]{2}{*}{$\begin{array}{l}\text { Dunlap, Clarke, } \\
\text { Jackson, Wright, } \\
\text { Ramos, \& } \\
\text { Brinson, } 1995\end{array}$} & \multirow[t]{2}{*}{$\begin{array}{l}\text { Analyze the } \\
\text { effects of a SM } \\
\text { package. }\end{array}$} & \multirow[t]{2}{*}{$\mathrm{ED}$} & \multirow[t]{2}{*}{$\begin{array}{l}\text { Elementary } \\
\text { School }\end{array}$} & \multirow[t]{2}{*}{ Self-Contained } & $\begin{array}{l}\text { Task } \\
\text { engagement }\end{array}$ & $\begin{array}{l}\text { Improved task } \\
\text { engagement that } \\
\text { remained } \\
\text { consistently high }\end{array}$ \\
\hline & & & & & $\begin{array}{l}\text { Disruptive } \\
\text { behavior }\end{array}$ & $\begin{array}{l}\text { Substantial } \\
\text { decrease }\end{array}$ \\
\hline \multirow[t]{2}{*}{$\begin{array}{l}\text { Kern \& Dunlap, } \\
1994\end{array}$} & \multirow[t]{2}{*}{$\begin{array}{l}\text { Assess the } \\
\text { effects of SM }\end{array}$} & \multirow[t]{2}{*}{ ED } & \multirow[t]{2}{*}{$\begin{array}{l}\text { Elementary } \\
\text { School }\end{array}$} & \multirow[t]{2}{*}{ Self-Contained } & $\begin{array}{l}\text { On-task } \\
\text { behavior }\end{array}$ & Increased \\
\hline & & & & & $\begin{array}{l}\text { Disruptive } \\
\text { behavior }\end{array}$ & Decreased \\
\hline
\end{tabular}




\begin{tabular}{|c|c|c|c|c|c|c|}
\hline Study & $\begin{array}{l}\text { Research } \\
\text { Question }\end{array}$ & $\begin{array}{l}\text { Disability } \\
\text { Category of } \\
\text { Participants }\end{array}$ & Grade Level & Setting & $\begin{array}{l}\text { Dependent } \\
\text { Variable }\end{array}$ & Results \\
\hline Gulchak, 2008 & $\begin{array}{l}\text { Examine SM on- } \\
\text { task behavior } \\
\text { using mobile } \\
\text { handheld } \\
\text { computers. }\end{array}$ & ED & $\begin{array}{l}\text { Elementary } \\
\text { School }\end{array}$ & Self-Contained & $\begin{array}{l}\text { On-task } \\
\text { behavior }\end{array}$ & Increased \\
\hline $\begin{array}{l}\text { Hallahan, Lloyd, } \\
\text { Kosiewicz, } \\
\text { Kauffman, \& }\end{array}$ & $\begin{array}{l}\text { Investigate the } \\
\text { effects of SM } \\
\text { independent of }\end{array}$ & LD & $\begin{array}{l}\text { Elementary } \\
\text { School }\end{array}$ & Self-Contained & $\begin{array}{l}\text { On-task } \\
\text { behavior }\end{array}$ & Increased \\
\hline Graves, 1979 & $\begin{array}{l}\text { backup } \\
\text { reinforcement. }\end{array}$ & & & & $\begin{array}{l}\text { Academic } \\
\text { productivity }\end{array}$ & Increased \\
\hline \multirow{2}{*}{$\begin{array}{l}\text { Hallahan, } \\
\text { Marshall, \& } \\
\text { Lloyd, } 1981\end{array}$} & $\begin{array}{l}\text { Investigate the } \\
\text { effects of SM }\end{array}$ & LD & $\begin{array}{l}\text { Elementary } \\
\text { School }\end{array}$ & Self-Contained & $\begin{array}{l}\text { Percent of time } \\
\text { on task }\end{array}$ & Increased \\
\hline & & & & & $\begin{array}{l}\text { Recording } \\
\text { accuracy }\end{array}$ & $\begin{array}{l}\text { Accuracy of } \\
\text { self-recording } \\
\text { may affect } \\
\text { success of the } \\
\text { treatment }\end{array}$ \\
\hline
\end{tabular}




\begin{tabular}{|c|c|c|c|c|c|c|}
\hline Study & $\begin{array}{l}\text { Research } \\
\text { Question }\end{array}$ & $\begin{array}{l}\text { Disability } \\
\text { Category of } \\
\text { Participants }\end{array}$ & Grade Level & Setting & $\begin{array}{l}\text { Dependent } \\
\text { Variable }\end{array}$ & Results \\
\hline \multirow[t]{2}{*}{$\begin{array}{l}\text { Harris, } \\
\text { Friedlander, } \\
\text { Saddler, } \\
\text { Frizzelle, \& } \\
\text { Graham, } 2005\end{array}$} & $\begin{array}{l}\text { Examine the } \\
\text { differential } \\
\text { effectiveness of } \\
\text { SMA versus } \\
\text { SMP. }\end{array}$ & ADHD & $\begin{array}{l}\text { Elementary } \\
\text { School }\end{array}$ & $\begin{array}{l}\text { General } \\
\text { Education }\end{array}$ & $\begin{array}{l}\text { On-task } \\
\text { behavior }\end{array}$ & $\begin{array}{l}\text { Increased on- } \\
\text { task behavior } \\
\text { and stability of } \\
\text { on-task behavior } \\
\text { with little } \\
\text { difference } \\
\text { between the two } \\
\text { monitoring } \\
\text { procedures }\end{array}$ \\
\hline & & & & & $\begin{array}{l}\text { Academic } \\
\text { performance }\end{array}$ & $\begin{array}{l}\text { Both monitoring } \\
\text { procedures } \\
\text { increased } \\
\text { academic } \\
\text { performance } \\
\text { with SMA } \\
\text { procedures } \\
\text { resulting in } \\
\text { higher levels of } \\
\text { academic } \\
\text { accuracy }\end{array}$ \\
\hline $\begin{array}{l}\text { Lloyd, Hallahan, } \\
\text { Kosiewicz, \& } \\
\text { Kneedler, } 1982\end{array}$ & $\begin{array}{l}\text { Compare the } \\
\text { reactive effects } \\
\text { of self- } \\
\text { assessment and } \\
\text { self-recording. }\end{array}$ & LD & $\begin{array}{l}\text { Elementary } \\
\text { School }\end{array}$ & Self-Contained & $\begin{array}{l}\text { On-task } \\
\text { behavior }\end{array}$ & $\begin{array}{l}\text { Self-recording } \\
\text { produced more } \\
\text { beneficial } \\
\text { reactive effects } \\
\text { than self- } \\
\text { assessment }\end{array}$ \\
\hline
\end{tabular}




\begin{tabular}{|c|c|c|c|c|c|c|}
\hline Study & $\begin{array}{l}\text { Research } \\
\text { Question }\end{array}$ & $\begin{array}{l}\text { Disability } \\
\text { Category of } \\
\text { Participants }\end{array}$ & Grade Level & Setting & $\begin{array}{l}\text { Dependent } \\
\text { Variable }\end{array}$ & Results \\
\hline & & & & & $\begin{array}{l}\text { Academic } \\
\text { productivity }\end{array}$ & Inconclusive \\
\hline $\begin{array}{l}\text { Mathes \& } \\
\text { Bender, } 1997\end{array}$ & $\begin{array}{l}\text { Investigate the } \\
\text { efficacy of SM } \\
\text { coupled with a } \\
\text { pharmacological } \\
\text { treatment plan in } \\
\text { classroom } \\
\text { settings. }\end{array}$ & $\begin{array}{l}\mathrm{LD} \\
\mathrm{ED} \\
\text { ADHD }\end{array}$ & $\begin{array}{l}\text { Elementary } \\
\text { School }\end{array}$ & Resource & $\begin{array}{l}\text { On-task } \\
\text { behavior }\end{array}$ & $\begin{array}{l}\text { Increased and } \\
\text { maintained } \\
\text { throughout } \\
\text { fading phases } \\
\text { Goal, } \\
\text { procedures, and } \\
\text { effects were } \\
\text { rated as socially } \\
\text { valid by teacher } \\
\text { and participants }\end{array}$ \\
\hline $\begin{array}{l}\text { McDougall \& } \\
\text { Brady, } 1995\end{array}$ & $\begin{array}{l}\text { Evaluate } \\
\text { participants' } \\
\text { performance } \\
\text { using self- } \\
\text { assessment and } \\
\text { self-recording. }\end{array}$ & ED & $\begin{array}{l}\text { Elementary } \\
\text { School }\end{array}$ & $\begin{array}{l}\text { Self-Contained } \\
\text { summer school }\end{array}$ & $\begin{array}{l}\text { Time on task } \\
\text { Academic } \\
\text { performance } \\
\text { SM accuracy }\end{array}$ & $\begin{array}{l}\text { Minimum level } \\
\text { of accuracy may } \\
\text { be required for } \\
\text { beneficial effects }\end{array}$ \\
\hline $\begin{array}{l}\text { Ninness, Fuerst, } \\
\text { \& Rutherford, \& } \\
\text { Glenn, } 1991\end{array}$ & $\begin{array}{l}\text { Assess a method } \\
\text { of inducing } \\
\text { transfer of self- }\end{array}$ & ED & Middle School & Self-Contained & $\begin{array}{l}\text { Off-task } \\
\text { behavior }\end{array}$ & $\begin{array}{l}\text { Prosocial } \\
\text { behavior of } \\
\text { students with }\end{array}$ \\
\hline
\end{tabular}




\begin{tabular}{|c|c|c|c|c|c|c|}
\hline Study & $\begin{array}{l}\text { Research } \\
\text { Question }\end{array}$ & $\begin{array}{l}\text { Disability } \\
\text { Category of } \\
\text { Participants }\end{array}$ & Grade Level & Setting & $\begin{array}{l}\text { Dependent } \\
\text { Variable }\end{array}$ & Results \\
\hline \multirow{6}{*}{$\begin{array}{l}\text { Prater, Joy, } \\
\text { Chilman, } \\
\text { Temple, \& } \\
\text { Miller, } 1991\end{array}$} & $\begin{array}{l}\text { managing } \\
\text { behavior. }\end{array}$ & & & & $\begin{array}{l}\text { Socially } \\
\text { inappropriate } \\
\text { behavior }\end{array}$ & $\begin{array}{l}\text { ED successfully } \\
\text { transferred from } \\
\text { the training } \\
\text { setting }\end{array}$ \\
\hline & \multirow{5}{*}{$\begin{array}{l}\text { Demonstrate the } \\
\text { effectiveness } \\
\text { and } \\
\text { generalizability } \\
\text { of SM } \\
\text { procedures. }\end{array}$} & $\mathrm{LD}$ & High School & Resource & \multirow{5}{*}{$\begin{array}{l}\text { On-task } \\
\text { behavior }\end{array}$} & \multirow{5}{*}{$\begin{array}{l}\text { Results support } \\
\text { the adaptability } \\
\text { and } \\
\text { generalizability } \\
\text { of SM }\end{array}$} \\
\hline & & LD & High School & Self-Contained & & \\
\hline & & $\mathrm{LD}$ & High School & Resource & & \\
\hline & & $\mathrm{LD}$ & Middle School & $\begin{array}{l}\text { Two general } \\
\text { education } \\
\text { classes }\end{array}$ & & \\
\hline & & $\mathrm{ED} / \mathrm{LD}$ & High School & $\begin{array}{l}\text { Two special } \\
\text { education } \\
\text { classes }\end{array}$ & & \\
\hline \multirow[t]{3}{*}{ Rock, 2005} & \multirow{3}{*}{$\begin{array}{l}\text { Evaluate the } \\
\text { effectiveness of } \\
\text { a combined } \\
\text { SMA and SMP } \\
\text { self-monitoring } \\
\text { intervention on } \\
\text { students with } \\
\text { different } \\
\text { academic and } \\
\text { behavioral } \\
\text { needs; and }\end{array}$} & \multirow{3}{*}{$\begin{array}{l}\text { Asperger } \\
\text { syndrome } \\
\text { Gifted } \\
\text { Floating Harbor } \\
\text { syndrome } \\
\text { LD/ADHD. LD } \\
\text { ADHD } \\
\text { Nondisabled }\end{array}$} & $\begin{array}{l}\text { Elementary } \\
\text { School }\end{array}$ & \multirow[t]{3}{*}{$\begin{array}{l}\text { General } \\
\text { education }\end{array}$} & $\begin{array}{l}\text { Academic } \\
\text { engagement and } \\
\text { disengagement }\end{array}$ & Increased \\
\hline & & & & & $\begin{array}{l}\text { Academic } \\
\text { disengagement } \\
\text { and non-targeted } \\
\text { problem } \\
\text { behavior }\end{array}$ & Decreased \\
\hline & & & & & $\begin{array}{l}\text { Academic } \\
\text { productivity }\end{array}$ & Increased \\
\hline
\end{tabular}




\begin{tabular}{|c|c|c|c|c|c|c|}
\hline Study & $\begin{array}{l}\text { Research } \\
\text { Question }\end{array}$ & $\begin{array}{l}\text { Disability } \\
\text { Category of } \\
\text { Participants }\end{array}$ & Grade Level & Setting & $\begin{array}{l}\text { Dependent } \\
\text { Variable }\end{array}$ & Results \\
\hline & $\begin{array}{l}\text { applicability } \\
\text { across various } \\
\text { stages of content } \\
\text { acquisition. }\end{array}$ & & & & $\begin{array}{l}\text { Academic } \\
\text { accuracy }\end{array}$ & Did not increase \\
\hline $\begin{array}{l}\text { Rooney, } \\
\text { Hallahan, \& } \\
\text { Lloyd, } 1984\end{array}$ & $\begin{array}{l}\text { Investigate SM } \\
\text { with } \\
\text { reinforcement on } \\
\text { a large group. }\end{array}$ & LD & $\begin{array}{l}\text { Elementary } \\
\text { School }\end{array}$ & $\begin{array}{l}\text { General } \\
\text { education }\end{array}$ & $\begin{array}{l}\text { On-task } \\
\text { behavior }\end{array}$ & Increased \\
\hline \multirow{2}{*}{$\begin{array}{l}\text { Shapiro, DuPaul, } \\
\& \text { Bradley-Klug, } \\
1998\end{array}$} & $\begin{array}{l}\text { Evaluate the } \\
\text { effects of SM. }\end{array}$ & ADHD/LD & Middle School & Self-contained & $\begin{array}{l}\text { On-task } \\
\text { behavior }\end{array}$ & Increased \\
\hline & & ADHD & & Resource & & \\
\hline \multirow{3}{*}{$\begin{array}{l}\text { Shimabukuro, } \\
\text { Prater, Jenkins, } \\
\text { \& Edelen-Smith, } \\
1999\end{array}$} & $\begin{array}{l}\text { Investigate the } \\
\text { effects of SM. }\end{array}$ & LD/ADHD & Middle School & Self-contained & $\begin{array}{l}\text { On-task } \\
\text { behavior }\end{array}$ & Increased \\
\hline & & & & & $\begin{array}{l}\text { Academic } \\
\text { accuracy }\end{array}$ & Increased \\
\hline & & & & & $\begin{array}{l}\text { Academic } \\
\text { productivity }\end{array}$ & Increased \\
\hline
\end{tabular}




\begin{tabular}{|c|c|c|c|c|c|c|}
\hline Study & $\begin{array}{l}\text { Research } \\
\text { Question }\end{array}$ & $\begin{array}{l}\text { Disability } \\
\text { Category of } \\
\text { Participants }\end{array}$ & Grade Level & Setting & $\begin{array}{l}\text { Dependent } \\
\text { Variable }\end{array}$ & Results \\
\hline & & & & & Social Validity & $\begin{array}{l}\text { Teacher reported } \\
\text { intervention was } \\
\text { easy to } \\
\text { implement, } \\
\text { appropriate for } \\
\text { the targeted } \\
\text { behaviors, and } \\
\text { relevant to } \\
\text { students' needs }\end{array}$ \\
\hline \multirow[t]{2}{*}{$\begin{array}{l}\text { Smith \& Young, } \\
1992\end{array}$} & \multirow[t]{2}{*}{$\begin{array}{l}\text { Examine the } \\
\text { effects of a self- } \\
\text { management } \\
\text { procedure that } \\
\text { includes peer- } \\
\text { evaluation and } \\
\text { goal-setting. }\end{array}$} & $\begin{array}{l}\mathrm{LD} \\
\mathrm{ED}\end{array}$ & High School & $\begin{array}{l}\text { Resource } \\
\text { General } \\
\text { education }\end{array}$ & $\begin{array}{l}\text { Off-task } \\
\text { behavior }\end{array}$ & $\begin{array}{l}\text { Decreased but } \\
\text { did not } \\
\text { generalize from } \\
\text { training setting } \\
\text { to general } \\
\text { setting }\end{array}$ \\
\hline & & & & & $\begin{array}{l}\text { Academic } \\
\text { behavior }\end{array}$ & $\begin{array}{l}\text { Increased but } \\
\text { did not } \\
\text { generalize }\end{array}$ \\
\hline \multirow[t]{2}{*}{$\begin{array}{l}\text { Wolfe, Heron, \& } \\
\text { Goddard, } 2000\end{array}$} & $\begin{array}{l}\text { Examine the } \\
\text { effects of SM. }\end{array}$ & $\mathrm{LD}$ & $\begin{array}{l}\text { Elementary } \\
\text { School }\end{array}$ & Resource & $\begin{array}{l}\text { On-task } \\
\text { behavior }\end{array}$ & Increased \\
\hline & & & & & $\begin{array}{l}\text { Academic } \\
\text { performance }\end{array}$ & Inconclusive \\
\hline
\end{tabular}




\begin{tabular}{|c|c|c|c|c|c|c|}
\hline Study & $\begin{array}{l}\text { Research } \\
\text { Question }\end{array}$ & $\begin{array}{l}\text { Disability } \\
\text { Category of } \\
\text { Participants } \\
\end{array}$ & Grade Level & Setting & $\begin{array}{l}\text { Dependent } \\
\text { Variable }\end{array}$ & Results \\
\hline & & & & & Social Validity & $\begin{array}{l}\text { General } \\
\text { consensus from } \\
\text { teachers and } \\
\text { participants that } \\
\text { using SM was a } \\
\text { positive } \\
\text { experience }\end{array}$ \\
\hline
\end{tabular}

Note. $\mathrm{SM}=$ self-monitoring. $\mathrm{SMA}=$ self-monitoring attention. $\mathrm{SMP}=$ self-monitoring performance.

$\mathrm{LD}=$ learning disability. $\mathrm{ED}=$ emotional disturbance. $\mathrm{ADHD}=$ attention deficit-hyperactivity disorder. 
Social Validity

According to social validity data, self-monitoring procedures are effective, age appropriate and practical for classroom implementation (Mathes \& Bender, 1997; Shimabukuro, Prater, Jenkins, \& Edelen-Smith, 1999). Students have expressed overall satisfaction with selfmonitoring procedures and effects (Mathes \& Bender, 1997, Shimabukuro, Prater, Jenkins, \& Edelen-Smith, 1999). Specifically, teachers have noted improvements in students' target behavior (Mathes \& Bender, 1997), and reported that self-monitoring procedures are easy to implement, and are relevant to students' needs (Shimabukuro, Prater, Jenkins, \& Edelen-Smith, 1999; Wolfe, Heron, \& Goddard, 2000).

\section{Self-Monitoring and Technology}

Self-monitoring has been highlighted as an effective intervention for students with high incidence disabilities in special and general education settings (Anderson \& Wheldall, 2004; Crum, 2004; Fitzpatrick \& Knowlton, 2009; Gulchak, 2008; Kern \& Dunlap, 1994; McDougall \& Brady, 1995; Mooney, Ryan, Uhing, Reid, \& Epstein, 2005; Ninness, Fuerst, Rutherford, \& Glenn, 1991). Based on prior research (Gulchak, 2008) and from recent reviews of selfmonitoring literature (Anderson \& Wheldall, 2004; Fitzpatrick \& Knowlton, 2009), selfmonitoring procedures and devices have remained primitive. For example, Anderson and Wheldall (2004) pointed out that a majority of prior research used tape-recorded audio tones to deliver cues for students to initiate self-monitoring. The tape recorders were either placed on or near the student's desk. Additionally, students often used headphones to hear the audio tones 
without distracting others in the classroom. Participants have found such cueing procedures embarrassing and annoying (Harris, Graham, Reid, McElroy, \& Hamby, 1994). Although cueing procedures have advanced somewhat (e.g., vibrating beeper, vibrating watch), only one study using technology has been conducted to date (Gulchak, 2008). Gulchak (2008) conducted a study to examine self-monitoring on-task behavior using a mobile handheld computer for an elementary student with ED. A Palm Zire 72 handheld computer was used as the self-monitoring device. Software was purchased and installed onto the device that allowed the researcher to create a self-monitoring form. The alarm on the calendar application of the device was scheduled to chime at 10-minute intervals at which point the student recorded the occurrence or nonoccurrence of the target behavior directly on the handheld computer using the researchercreated self-monitoring form. Data revealed that the student was able to self-monitor on-task behavior using a mobile handheld computer and that the self-monitoring procedures effectively increased the student's on-task behavior. The researcher also noted that the teacher was able to teach the student the self-monitoring procedures using the handheld computer, the student expressed excitement about using the handheld computer, and the handheld computer was less stigmatizing and obtrusive than traditional recording materials.

Gulchak's findings demonstrate that technology is capable of propelling self-monitoring into the technology age by making self-monitoring procedures discreet, mobile, and increase the overall social validity of self-monitoring (Gulchak, 2008). As such, using technological device that is socially acceptable and has the functionality for serving as a self-monitoring device may 
be the most practical way to update self-monitoring procedures. A cell phone is one such device that meets both criteria. First, cell phones are socially acceptable. The prevalence of cell phones among those who are school-aged is indisputable. According to the Pew Internet \& American Life Project (2009), 71\% of teens 12 to 17 years old owned a cell phone while only $60 \%$ of those owned a desktop or laptop computer. The Project further revealed that the largest increase in cell phone ownership occurred during the transition between middle and high school. Over half of the 12 to 13 year olds surveyed owned a cell phone and rose to $84 \%$ by the age of 17 . Second, cell phones have the functionality to serve as self-monitoring devices. For example, the vibrating text message alert can be used to remind a student to assess his or her behavior instead of an audio tone while responding to the text message is the equivalent to paper and pencil recording. As such, replacing tape recorders and paper and pencil with cell phones for selfmonitoring procedures has the potential to strengthen the practicality and social validity of selfmonitoring procedures across settings.

\section{Summary}

This research study was grounded on the increasing number of students with high incidence disabilities being placed in inclusive settings and the range of behaviors typically exhibited by such students that hinder their ability to function in inclusive settings. The researcher sought to determine if an updated self-monitoring procedure that used cell phone technology would produce positive effects consistent with those reported throughout the research literature (Anderson \& Wheldall, 2004; Crum, 2004; Fitzpatrick \& Knowlton, 2009; Gulchak, 
2008; Kern \& Dunlap, 1994; McDougall \& Brady, 1995; Mooney, Ryan, Uhing, Reid, \& Epstein, 2005; Ninness, Fuerst, Rutherford, \& Glenn, 1991) while maintaining the social validity of traditional self-monitoring procedures. 


\title{
CHAPTER THREE: METHODOLOGY
}

\author{
$\underline{\text { Introduction }}$
}

The purpose of this chapter is to present the method that was employed to conduct the study. First, the chapter opens with the purpose of the study followed by the research questions. Next, the participants and settings are discussed followed by a thorough explanation of the research design. Finally, the chapter closes with a description of the study procedures and data analyses.

\section{Purpose of the Study}

Prior research has demonstrated positive effects of self-monitoring on targeted behavior of students with and without disabilities (Crum, 2004; Fitzpatrick \& Knowlton, 2009; Glynn \& Thomas, 1974; Gulchak, 2008; Kern \& Dunlap, 1994; McDougall \& Brady, 1995; Mooney, Ryan, Uhing, Reid, \& Epstein, 2005; Ninness \& Fuerst, 1995; Ninness, Fuerst, Rutherford, \& Glenn, 1991; Rock, 2005; Santogrossi, O’Leary, Romanczyk, \& Kaufman, 1973; Wood, Murdock, Cronin, Dawson, \& Kirby, 1998). A review of the literature conducted by Anderson and Wheldall (2004) revealed that self-monitoring improves student behavior and increases independence by decreasing reliance on externally administered reinforcement. Self-monitoring is a proactive intervention that can be individualized and implemented across settings (Anderson 
\& Wheldall, 2004). However, procedures and devices used to self-monitor have not kept up with emerging technology (Fitzpatrick \& Knowlton, 2009; Gulchak, 2008). For example, traditional cueing procedures utilize tape-recorded audio tones that require either a tape recorder placed on or near the student's desk and headphones so the student can hear the audio tones without distracting other students. Participants have found that such cueing procedures are embarrassing and annoying (Harris, Graham, Reid, McElroy, \& Hamby, 1994). Additionally, recording procedures rarely deviate from paper and pencil recording. Only one study conducted by Gulchak (2008) utilized technology, specifically personal digital devices (PDAs), for students with emotional disturbance to record their monitored behavior. Although self-monitoring procedures have advanced somewhat with the introduction of vibrating beepers and watches for cueing and PDAs for recording; a study has not been conducted that utilizes cell phone technology concurrently for the cueing and recording components of self-monitoring. A selfmonitoring procedure that uses cell phone technology has the potential to make the researchbased intervention more conducive to inclusive settings by being mobile and more discreet than procedures traditionally used to self-monitor. Therefore, the purpose of the research study was to extend the research literature by, first, determining the effects of CellF-Monitoring, a selfmonitoring procedure that utilized cell phone technology for cueing and recording, on the ontask behavior of students with high incidence disabilities in inclusive settings; and second, determining the social validity of the CellF-Monitoring procedure in inclusive settings. 


\section{$\underline{\text { Research Questions }}$}

1. How will CellF-Monitoring, a self-monitoring procedure that utilizes cell phone technology for cueing and recording affect the on-task behavior of middle school students with high incidence disabilities in inclusive settings?

2. How will middle school general education teachers, middle school special education teachers, and middle school students with high incidence disabilities rate the social validity of the CellF-Monitoring procedure?

\section{$\underline{\text { Ethical Considerations }}$}

Prior to conducting the study, the researcher sought and obtained approval by the Institutional Review Board to conduct human subject research through the university's Office of Research (see APPENDIX A INSTITUTIONAL REVIEW BOARD LETTER OF APPROVAL). Next, a request to conduct research in a public school was submitted for district approval. Once permission was granted by the district to proceed with the study, recruitment procedures were initiated.

\section{$\underline{\text { Participants }}$}

Student participants were defined as students (a) with a high incidence disability (e.g., learning disability, emotional disturbance) as defined by the state of Florida or medically diagnosed with attention deficit-hyperactivity disorder and served under the Individuals with Disabilities Education Act (2004) as determined by the state of Florida; (b) who are included in at least one core general education class; (c) who are teacher-identified as exhibiting off-task 
behavior at a frequency that impedes academic progress; (d) who have an attendance rate of $90 \%$ or higher, (e) who return the consent form signed by a parent/guardian; and (f) who assent to participation in the research study. General education teacher participants were defined as (a) the general education teacher of record for a core general education class in which students who met student participant eligibility requirements were enrolled and (b) who consented to participate in the research study. Special education teacher participants were defined as (a) the special education teacher who provided special education services to students who met student participant eligibility requirements and (b) consented to participate in the research study.

The researcher began the recruitment process by obtaining administrative support from a middle school from the local school district. The researcher gave a brief presentation and passed out flyers about the research study to local school administrators attending a school-university partnership meeting. Local school administrators who had pre-existing relationships with the university attended the partnership meeting. The presentation yielded one principal and one special education specialist from different middle schools who expressed an interest in the research study. The researcher met with the principal and specialist individually to discuss specific procedures of the research study. The principal from the first middle school was supportive of the research study and gave permission to proceed with the study on his campus if the device could be changed from a cell phone to an IPod. His middle school had instituted and strictly enforced a no-cell phone policy since the beginning of the school year and felt that allowing the researcher to conduct the study would compromise enforcement of the policy. The 
researcher explained that the cell phone was the focal point of the study and could not be changed. As such, the principal did not give the researcher permission to proceed with the research study at his middle school. The special education specialist from the second middle school met with the school principal to present the research study, which resulted in the principal granting permission to conduct the study at his middle school.

After obtaining permission and support from the middle school principal, the researcher recruited teacher and student participants by meeting with the special education specialist to identify teachers who were eligible to participate in the research study. An informational meeting was scheduled for all eligible teachers to provide an overview of the research study and schedule individual follow-up meetings with those interested in participating in the study. One meeting was scheduled with a general education teacher and a special education teacher that cotaught a Language Arts class. During the follow-up meeting, the researcher and both teacher participants discussed specific procedural details and established a timeline for the study. The researcher also provided each teacher participant with a consent document to keep for their records that disclosed that (1) the activities involve research, (2) participation is voluntary, (3) the procedures to be performed, and (4) the name and contact information of the researcher (see APPENDIX B TEACHER CONSENT DOCUMENT).

Once both teacher participants agreed to the study, the researcher asked the special education teacher to identify students who met eligibility requirements and send parent/guardian consent documents home to obtain parent/guardian consent to participate in the research study 
(see APPENDIX C PARENT CONSENT DOCUMENT). The parent/guardian consent document also disclosed that (1) the activities involve research, (2) participation is voluntary, (3) the procedures to be performed, and (4) the name and contact information of the researcher. The parent/guardian consent document required a parent/guardian signature to indicate that permission had been given for the student to participate in the study. Once parental consent was obtained, an assent meeting was scheduled with eligible students to ensure that the students understood what they would be asked to do and that they were free to decide whether or not to participate. Four students were identified as eligible for participation in the study and were given parent/guardian consent documents to take home. Two students returned signed parent/guardian consent documents, the third student's parent did not provide consent to participate, and the fourth student did not return the parent/consent document. The special education teacher participant followed up with the fourth student's parent by phone to answer any questions or address any concerns that the parent may have but was unable to reach the parent within the time allocated to obtain consent. As a result, the recruitment procedures yielded one middle school principal, one general education teacher participant, one special education teacher participant, and two student participants. Student participant characteristics are illustrated in Table 2.

Table 2. Participant Characteristics

\begin{tabular}{|c|c|c|c|c|c|}
\hline Participant & Gender & Grade & Age & $\begin{array}{l}\text { Disability } \\
\text { Category }\end{array}$ & $\begin{array}{l}\text { FCAT } \\
\text { reading level }\end{array}$ \\
\hline
\end{tabular}




\begin{tabular}{|c|c|c|c|c|c|}
\hline Participant 1 & Male & 7 & 13 & ADHD/OHI & Level 2 \\
\hline Participant 2 & Male & 7 & 14 & SLD & Unavailable \\
\hline
\end{tabular}

Note. $\mathrm{ADHD}=$ attention deficit-hyperactivity disorder. $\mathrm{OHI}=$ other health

impaired. SLD = specific learning disability.

\section{$\underline{\text { Setting }}$}

The District

The study took place in a large urban district located in central Florida. The Florida Department of Education Bureau of Exceptional Education and Student Services released a 2010 Local Education Agency (LEA) Profile. According to the 2010 LEA Profile, the district has 211 schools, and educates over 170,000 students, approximately $13 \%$ of which were served under IDEA. District-wide racial/ethnic distribution data revealed that $33 \%$ of students with disabilities are White, 29\% are Black, 34\% are Hispanic, and 2\% are Multiracial. Additionally, Asian/Pacific Islanders and American Indian/Alaskan Native accounted for 5\% and less than $1 \%$ of students with disabilities, respectively. Graduation data from the 2008-2009 school year reported that $57 \%$ of students with disabilities graduated from high school with a standard diploma compared to the state average of $50 \%$. Approximately $2 \%$ of students with disabilities dropped out of school during the 2008-2009 school year compared to the state average of $4 \%$. Placement data for the 2009-20010 school year revealed that approximately $70 \%$ of students with disabilities spent $80 \%$ or more of the school week with peers without disabilities while 11 and $15 \%$ of students spent $40-80 \%$ and less than $40 \%$ with peers without disabilities respectively. Data for the 2008-2009 school year indicated that less than $1 \%$ of students with 
disabilities were suspended/expelled for greater than 10 days but data were not disaggregated by disability.

The School

This study took place in a public middle school located in the central Florida area. According to U.S. Department of Education's Common Core of Data database website, the research site is a midsize regular school that served approximately 1,125 students in grades 6-8 during the 2007-2008 school year; approximately .3\% of which were American Indian/Alaskan, $3 \%$ were Asian, $9 \%$ were Black, $15 \%$ were White, and $71 \%$ were Hispanic. Approximately $15 \%$ of the students were eligible for reduced-price lunch and $65 \%$ for free lunch.

\section{The Class}

The classroom in which this study took place was a $7^{\text {th }}$ grade Language Arts class with one highly qualified general education teacher and one highly qualified special education teacher. The general education and special education teachers practiced the one teach-one drift model of co-teaching where the general education teacher provided the majority of the instruction and the special education teacher supported the instruction with accommodations, modifications, and individual support as needed (Friend \& Cook, 2003). The class was the last of 7 periods that met each day of the week. Approximately 21 students were enrolled in the class; 4 of which were students with disabilities. The students sat in assigned seats and were organized in rows that faced a whiteboard in the front of the classroom. Participant 1 sat in the last seat in a row located in the center of the classroom. Participant 2 sat in the second seat in a 
row located near the door on the right side of the classroom. The classroom teachers established a daily routine that began with bell work, followed by whole group instruction and guided practice, and ended with independent practice and individual assistance.

\section{$\underline{\text { Variables }}$}

\section{Independent Variable}

The independent variable in this study was CellF-Monitoring, a researcher-developed self-monitoring procedure that utilized cell phone technology. Self-monitoring was defined as a procedure by which the participant is (1) provided with a cue, (2) assesses the occurrence or nonoccurrence of the target behavior, and (3) records the occurrence or nonoccurrence of the target behavior (Nelson \& Hayes, 1981). The CellF-Monitoring procedure utilized a cell phone to update two of the components of self-monitoring, cueing and recording. The cueing component was updated using a cell phone by sending text messages to the student participants' cell phones four times during the experimental class period at fixed intervals. The text messages served as cues to the student participants to self-assess the targeted behavior. The recording component was updated using a cell phone by having the student participants record the occurrence or nonoccurrence of the targeted behavior by responding to each of the four text message cues on the cell phone.

\section{The Cell Phones}

The study used prepaid, no-contract phones to maximize control over the functionality of the cell phones and to minimize inappropriate use of the cell phones by the student participants. 
The Virgin Mobile Kyocera Jax cell phone was chosen for the study based on functionality, appearance, and cost. Functionality of the cell phone was the first priority for choosing the cell phone. It was imperative that the cell phone have text message capabilities and vibrate as an option for incoming text message alerts. Next, appearance was considered. The Kyocera Jax is a standard "candy bar" phone. The approximate dimensions of each phone are 4.3 in $\mathrm{x} 1.7$ in $\mathrm{x}$ $.5 \mathrm{in}$; weighs $2.5 \mathrm{oz}$; and has a screen size of $1.8 \mathrm{in}$, which is consistent with current, popular cell phone models and would be inconspicuous in inclusive settings. Finally, cost was considered. Since the study was researcher-funded, the cost of each cell phone needed to be kept to a minimum while maintaining functionality. The Kyocera Jax cell phone costs approximately $\$ 14.99$ plus tax at most Best Buy stores or $\$ 9.99$ plus tax on the Virgin Mobile website (www.virginmobileusa.com). The researcher purchased one cell phone from a local Best Buy store first to assess functionality of the cell phone in person before purchasing the number of cell phones required for the study. Once the cell phone was purchased from Best Buy, the researcher activated the cell phone on the Virgin Mobile website. The website provided step-by-step directions to activate, choose a plan, and receive the phone number. The entire activation process took less than 10 minutes. A Virgin Mobile Texter's Delight plan was purchased for the cell phone that included 1000 text messages per month for $\$ 14.99$. After testing the functionality of the cell phone for the purposes of the study, the researcher purchased an additional phone from Best Buy. The second cell phone was activated using the same steps used to activate the first cell phone. 


\section{$\underline{\text { Text Message Cues }}$}

Each student participant received four text message cues on the cell phone at fixed intervals throughout each observation session in the experimental classroom. The text message cues and the students' replies had to be alternated because the social network used to exchange text messages did not allow duplication of messages. In other words, the same message could not be sent twice in a row. The first and fourth text message cues were composed ahead of time and scheduled to be sent to each participant at predetermined dates and times by the researcher. A social networking application was used in conjunction with a third party application to compose, schedule, send, and receive text message cues to and from cell phones. The second and third text message cues were composed and sent directly from the researcher's cell phone during the observation session to compare the researcher's observation with the student participants' response at the same point in time.

The Twitter social networking application was used as the central location through which all text message cues and replies between the researcher and student participants were exchanged (see Figure 1). Twitter is a social networking application where friends, family, and co-workers can communicate the exchange of quick, frequent messages of 140 characters or less, called tweets (www.twitter.com). The tweets are posted to your profile and can be forwarded to a cell phone as text messages. In order for text message cues and replies to be exchanged as tweets through Twitter, the researcher had to create and configure free Twitter accounts for the researcher and each student participant. First, the researcher registered for three different Twitter 
accounts (www.twitter.com); a researcher account and two student participant accounts. The researcher used generic usernames and passwords for each of the three accounts (e.g., student1 for username and password). Second, each of the three accounts was set to private to ensure that only student participants received the researcher's text message cues, or tweets, and only the researcher received the student participants' replies, or tweets. Third, each student participant account was set to follow the researcher account and the researcher account was set to follow each student participant account. Student participant accounts did not follow each other to ensure that participants only received tweets sent by the researcher and not Tweets sent by the other student participant. Lastly, the researcher enabled the mobile feature for each of the three accounts. The mobile feature allowed each student participant to receive the tweets on his cell phone and the researcher to receive each of the student participant's tweets on her cell phone. Once the Twitter accounts were created and configured, access to the Twitter website was not required by teacher participants, student participants, or the researcher during school hours. 


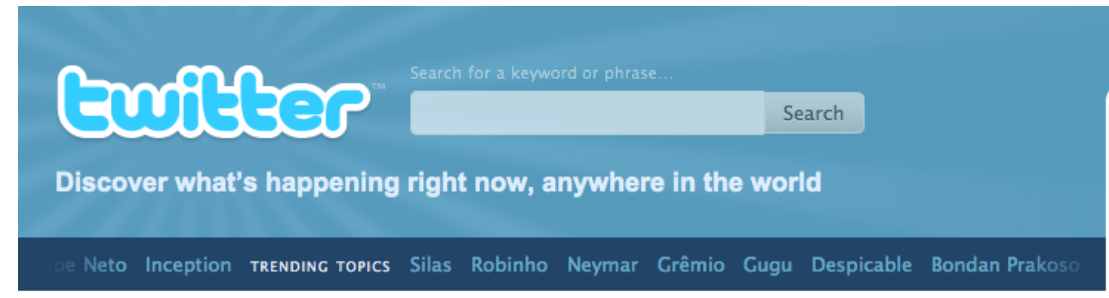

See who's here

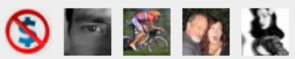
-17. 圆 826 䑸 0

Friends and industry peers you know. Celebrities you watch. Businesses you frequent. Find them all on Twitter.
Top Tweets Viewall >

DoyinakaLyricaL \#SongsThatNeverGetOld...Beat it...Smooth Criminal...Remember the Time...Thriller..basically all MJ classics...R.I.P. 55 minutes ago

iKineticalDummy If you tweet nonsense stuffs like "Now eating, now swimming, now sleeping, now opening my cupboard" ..\#TimeToLogOffTwitter

33 minutes ago

JackAllTimeLow Everyone left me in the car, this is Jurassic Park all over again

29 minutes ago

\section{Have an account? Sign in}

\section{New to Twitter?}

Twitter is a rich source of instant information. Stay updated. Keep others updated.

It's a whole thing.

\section{Sign Up ,}

Customize Twitter by choosing who to follow. Then see tweets from those folks as soon as

they're posted.

Using Twitter for a business?

Check out Twitter 101

Figure 1. Twitter Home Page.

The scheduled text message cues, or tweets, were sent to the student participants' cell phones twice during each observation session in the experimental classroom at fixed intervals using a third-party application called HootSuite (see Figure 2). HootSuite is a Professional Social Media Dashboard where individuals and companies can manage multiple social networking profiles and track followers (www.hootsuite.com). The researcher registered for a free HootSuite account and linked the researcher and student participant Twitter accounts to the HootSuite account. In addition to providing a platform to compose and schedule text message cues, HootSuite allowed the researcher to follow all text message cues sent and all student participant replies in one window on a computer (see Figure 3). 


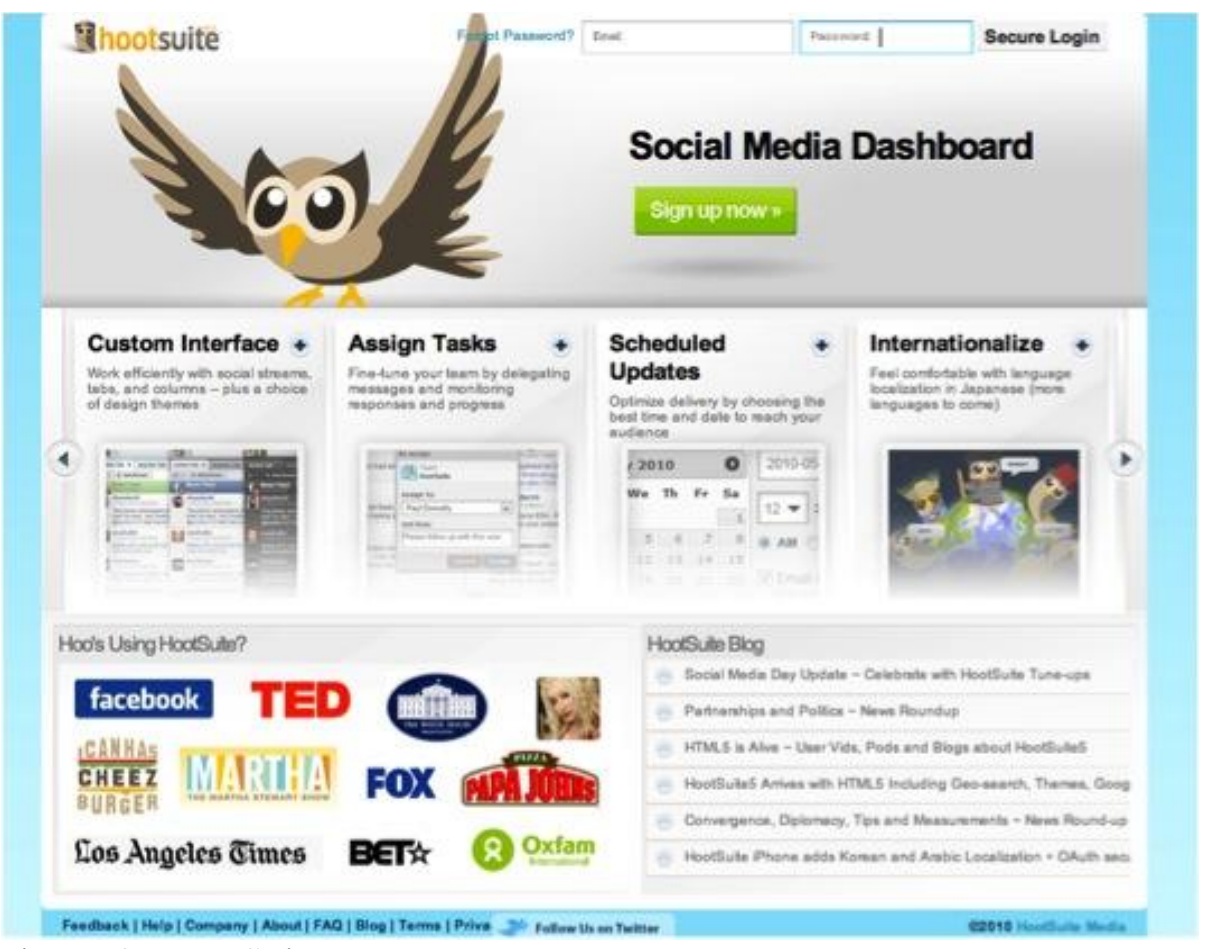

Figure 2. HootSuite Home Page. 

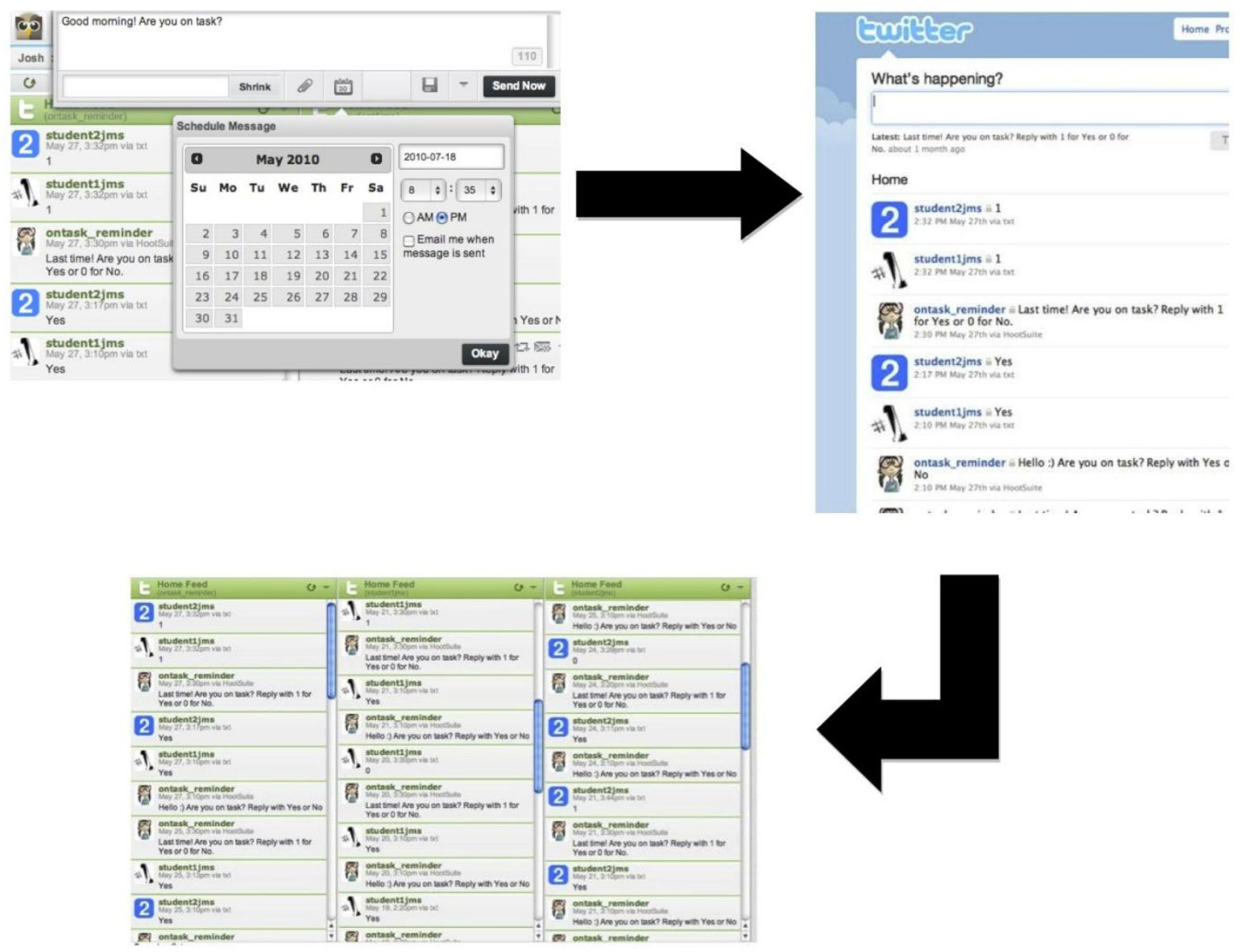

Figure 3. CellF-Monitoring Cueing Procedure.

Dependent Variables

The study had two dependent variables: (1) on-task behavior and (2) the social validity of the intervention. The first dependent variable, on-task behavior, was operationally defined as: (a) in seat (buttocks were on the seat of the chair unless given permission, student's feet do not have to be on the floor, all four feet of chair do not have to be on the floor), (b) quiet, unless given permission to speak (not talking, whispering, or mouthing to others without permission), (c) not disrupting others (passing a note, touching another student's body or possessions), (d) 
following teacher directions, and (e) eyes on the task, teacher, or speaker. On-task behavior was measured by direct observation using momentary time sampling with 1-minute intervals.

Momentary time sampling was chosen for this study because it allowed one observer to record the behavior of multiple participants during the same observation session (Kennedy, 2005) and accommodated data collection over long periods of time (Gunter, Venn, Patrick, Miller, \& Kelly, 2003). One-minute intervals were chosen to minimize the underestimation or overestimation of the occurrence of the observed behavior that occurred as a function of the duration and frequency of the behavior and the length of the intervals (Kennedy, 2005). The data collected were used to estimate the percentage of time on task for each observation session by dividing the number of intervals marked as on task by the total number of intervals observed and multiplied by 100 .

The second dependent variable was the social validity of the CellF-Monitoring procedure. An intervention is considered socially valid if the target behavior is socially relevant; the intervention procedures can be implemented by classroom teachers with fidelity using available resources; and the intervention produces positive outcomes (Horner et al., 2005). A questionnaire was provided to each participant that addressed the social relevance of the targeted behavior, the intervention procedures as observed by the teacher and used by the student participants, and the behavioral outcomes of the intervention (see APPENDIX D SOCIAL VALIDITY QUESTIONNAIRE). Teacher and student participant responses on a social validity questionnaire were used to determine the social validity of the intervention. 


\section{$\underline{\text { Research Design }}$}

Single-subject research was employed for the purposes of this study. Single-subject research is (a) practical for evaluating behavioral interventions, (b) practical for evaluating behavioral interventions in typical classroom settings, and (c) cost-effective (Horner, Carr, Halle, McGee, Odom, \& Wolery, 2005). In order to provide a high level of experimental rigor, the researcher followed the quality indicators for single-subject research suggested by Horner, Carr, Halle, McGee, Odom, and Wolery (2005) that include specifications for participants and settings, dependent variable, independent variable, baseline, internal validity, external validity, and social validity.

The researcher utilized a multiple-baseline-across-participants design to determine the effects of CellF-Monitoring, a self-monitoring procedure that utilized cell phone technology on the on-task behavior of middle school students with high incidence disabilities in inclusive settings. A multiple-baseline-across-participants design was chosen for the purposes of this study to, first, determine the effects of the intervention; and, second, to demonstrate the effectiveness of the intervention by replicating the treatment effects on an additional participant instead of withdrawing the intervention once implemented (Baer, Wolf, \& Risley, 1968; Kazdin, 1982; Tawney \& Gast, 1984). Multiple-baseline designs replicate treatment effects by gradually introducing the intervention to different baselines such as behaviors, individuals, or conditions (i.e., situations, settings, or time). Once treatment effects are demonstrated in one baseline, the intervention is introduced to the next baseline (Kazdin, 1982; Tawney \& Gast, 1984). Multiple- 
baseline designs require only two baselines to show a replicated effect (Kennedy, 2005). As such, this study met the minimum requirements for demonstrating the effectiveness of the intervention by targeting two baselines (i.e., two participants).

In addition to identifying effective interventions, single-subject research also identifies interventions that functionally relate to socially relevant outcomes. According to Horner et al. (2005), socially relevant interventions are identified by research procedures and findings that are socially valid, or practical. In other words, interventions are socially valid if the research procedures and findings are socially valid. Social validation of single-subject research, and interventions, occurs at three levels (Horner, Carr, Halle, McGee, Odom, \& Wolery, 2005; Wolf, 1978). The first level is targeting a dependent variable that is socially relevant. The second level is demonstrating that the independent variable, or intervention, can be applied with fidelity by teachers in typical classroom settings. The third level is demonstrating that teachers find the intervention procedures acceptable, applicable with available resources, and effective. For the purposes of this study, questionnaires were used to determine the social validity of the CellFMonitoring procedure.

\section{Internal Validity}

Internal validity refers to the extent to which the researcher can rule out extraneous variables and be confident that the independent variable is what changed the dependent variable (Kazdin, 1982; Kennedy, 2005). According to Horner et al. (2005), “single subject research designs provide experimental control for most threats to internal validity and, thereby, allow 
confirmation of a functional relationship between manipulation of the independent variable and change in the dependant variable" (p. 168). Typically, experimental control is demonstrated by documenting treatment effects at three different times with a single participant or across different participants (Horner et al., 2005). Specifically, multiple-baseline research designs demonstrate experimental control by the "staggered introduction of the independent variable at different points in time" (Horner et al., 2005, p. 168).

Eight types of threats to internal validity are known to exist (Kazdin, 1982; Kennedy, 2005; Tawney \& Gast, 1984): (1) history effects, (2) maturation effects, (3) testing effects, (4) instrumentation effects, (5) regression to the mean, (6) participant selection bias, (7) selective attrition of participants, and (8) interactions among selective attrition and other threats. Of the eight known threats to internal validity, the researcher identified history effects, maturation effects, instrumentation effects, and participant selection bias as threats to this study. First, the researcher addressed history and maturation effects by demonstrating treatment effects across participants. Next, to address instrumentation effects, trained inter-observers conducted $40 \%$ of the observations. Lastly, participant selection bias was addressed to the maximum extent possible; however, the scope of the research coupled with limited access to a wide range of diverse populations contributed to participant selection bias.

\section{External Validity}

External validity "refers to the extent to which the results of an experiment can be generalized or extended beyond the conditions of the experiment" (Kazdin, 1982, p. 81). 
Replication on participants, settings, materials, and/or behaviors strengthen external validity even if a study involves only one participant (Horner et al., 2005) and is the primary means of establishing external validity in behavioral science (Barlow \& Hayes, 1979). This study demonstrated external validity by replicating treatment effects across more than one participant. Spill-over effect, where improved behavior of participants increases the likelihood of improved behavior of the other participants (Kazdin, 1982; Kennedy, 2005), was determined to be a threat to external validity. During initial observations, the researcher noted that minimal interaction between the student participants and assigned seating at opposite sides of the room minimized the threat of any spill-over effects.

\section{Reliability}

Reliability, or inter-observer agreement "refers to the extent to which observers agree in their scoring of behavior" (Kazdin, 1982, p 48). According to Kazdin (1982), reliability is critical when different observers are recording behavior for three reasons. First, consistency between observers minimizes variation in the data and allows researchers to establish a pattern of behavior. Second, evaluating observer agreement moderates the effects of observer bias and ensures consistent response definitions over time. Third, consistency in observer agreement is an indication that the target behavior is operationally defined with a clear distinction between its occurrence and nonoccurrence. 


\section{$\underline{\text { Inter-Observer Agreement }}$}

The three most common methods of calculating inter-observer agreement are frequency ratio, or total agreement; point-by-point agreement, or interval agreement (Kazdin, 1982; Kenney, 2005; Tawney \& Gast, 1984); and occurrence/nonoccurrence agreement (Kennedy, 2005). Frequency ratio is used to determine the agreement between the totals of two or more independent observers (Kazdin, 1982). However, frequency ratio does not determine the agreement of each instance of recorded behavior, only agreement of the total frequency counts of recorded behavior (Kazdin, 1982; Kennedy, 2005). A more precise assessment of agreement is point-by-point agreement (Kazdin, 1982; Kennedy, 2005; Tawney \& Gast, 1984). Unlike frequency ratio, point-by-point agreement ratio assesses agreement between observers for each instance of recorded behavior (Kazdin, 1982). An even more stringent method of assessing inter-observer agreement is to calculate interval agreement for both the occurrence and nonoccurrence of behavior (Kennedy, 2005). According to Kennedy (2005), “this approach allows for the calculating of two agreement coefficients: one for the occurrence of the response and one for the nonoccurrence of the response" (p. 117).

For the purposes of this research study, the researcher used point-by-point agreement as an overall index of inter-observer agreement and occurrence/nonoccurrence agreement to "fully characterize the degree to which consistency was obtained by different observers" (Kennedy, 2005, p. 118). First, point-by-point agreement was calculated using the following formula (Kazdin, 1982; Kennedy, 2005) and steps (Kennedy, 2005, p. 116): 


$$
\left(\frac{\text { Agreements }}{\text { Agreements }+ \text { Disagreements }}\right) \times 100
$$

Step 1: Score each interval as an agreement or disagreement

Step 2: Sum the number of agreements

Step 3: Sum the number of disagreements

Step 4: Divide the number of agreements by the number of agreements plus disagreements

Step 5: Multiply the quantity from Step 4 by 100

Second, occurrence and nonoccurrence was calculated by using the same formula used to calculate point-by-point agreement. Two calculations were conducted and reported separately for agreement of occurrence and agreement of nonoccurrence (Kennedy, 2005).

\section{Inter-Observer Training}

The systematic inter-observer training was conducted as suggested by Kennedy (2005). The training took place in a designated training room at the university and lasted approximately two hours. Observation materials included the operationally defined target behavior (on-task behavior), the recording instrument, an MP3 player, and one pair of earbuds. First, the interobserver was provided with the operationally defined target behavior, on-task. The researcher demonstrated examples and nonexamples of on-task behavior in accordance with the operational definition used for the study. Next, the inter-observer was trained to use the recording instrument. The inter-observer was directed to use "1" to indicate the occurrence of the targeted 
behavior and " 0 " to indicate nonoccurrence of the targeted behavior. Third, the inter-observer was given the MP3 player and one pair of earbuds. The MP3 player contained a file with audio tones indicating the end of each 1-minute observation interval. The inter-observer knew how to operate the MP3 player so no practice was needed. A practice session was conducted in the experimental classroom. The researcher and the inter-observer observed the student participants and compared observations to ensure that the inter-observer accurately discriminated between the occurrence and nonoccurrence of the targeted behavior.

\section{Procedures}

This study was conducted in three phases: (1) baseline phase, (2) intervention phase, and (3) post-intervention phase. The baseline phase included data collection on the on-task behavior of the student participants before implementation of the intervention. The intervention phase included: (a) teacher participant training, (b) student CellF-Monitoring training, and (c) implementation of the intervention. The post-intervention phase included dissemination of the social validity questionnaires.

\section{Observation and Recording Procedures}

The researcher conducted twenty-minute observations at approximately the same time each day using momentary time sampling with 1-minute intervals (see APPENDIX E OBSERVATION RECORDING SHEET). Direct observation began approximately ten minutes after the tardy bell rang and continued for twenty minutes. Direct observation of the participants alternated with each interval. For instance, the observer recorded the occurrence or 
nonoccurrence of the behavior for the first student participant at the end of the first interval and then recorded the occurrence or nonoccurrence of the behavior for the second student participant at the end of the second interval, which resulted in 20 observations for each student participant during each observation session. Each member of the research team (i.e., researcher and trained inter-observer) used an MP3 player containing a file with audio tones indicating the end of each 1-minute interval at which point the occurrence or nonoccurrence of the targeted behavior was recorded. The observer recorded a " 1 " if the student participant was on-task and a " 0 " if the student participant was not on-task at the time the audio tone was heard.

\section{Baseline Phase}

Baseline data were collected for each student participant in the experimental classroom for at least four days prior to implementation of the intervention. Baseline data were collected for Participant 1 until a clear pattern of behavior was established. A clear pattern of behavior was established when three consecutive data points did not vary more than $50 \%$ from the mean. Once the criterion was met for establishing a clear pattern of behavior, a phase-change occurred from the baseline phase to the experimental phase. For Participant 2, baseline data were collected until a clear pattern of behavior was established by the first participant during the intervention phase at which point the intervention was implemented for the second participant. Decisions to change from baseline to experimental phases were not solely based on this criterion. Factors such as level, trend, and time spent in baseline were considered in phase-change decisions. 


\section{Intervention Phase}

\section{Teacher Participant Training}

The researcher conducted a teacher participant training to establish teacher behavior protocols for the experimental phase. The training took place in the general education teacher participant's classroom with both participating teachers and lasted approximately thirty minutes. The teachers were given a protocols sheet (see F TEACHER PROTOCOLS) that specifically outlined the parameters of teacher behaviors for the duration of the study. The researcher began the training session by defining traditional self-monitoring as a procedure by which a student (1) is provided with a cue to (2) assess the occurrence or nonoccurrence of the target behavior and (3) record the occurrence or nonoccurrence of the target behavior (Nelson \& Hayes, 1981); and on-task behavior as (a) in seat (buttocks were on the seat of the chair unless given permission, student's feet do not have to be on the floor, all four feet of chair do not have to be on the floor), (b) quiet, unless given permission to speak (not talking, whispering, or mouthing to others without permission), (c) not disrupting others (passing a note, touching another student's body or possessions), (d) following teacher directions, and (e) eyes on the task, teacher, or speaker. Next, the researcher explained the procedures for each component of the CellF-Monitoring procedure in detail. Finally, the researcher stressed the importance of consistency of teacher behavior in the experimental classroom in establishing experimental control and asked that the teachers remained consistent with the provision of specific and general praise/feedback; individual and group contingency plans; and disciplinary actions that were established prior to 
participation in the study. In other words, the teachers were asked not to change the way they typically interacted with the student participants once the study began.

\section{$\underline{\text { Student CellF-Monitoring Training }}$}

The researcher developed the training sequence, Three Steps to CellF-Monitoring, by adapting King-Sears and Bonfils’ (1999) self-management design-and-instruction sequence, SPIN. The SPIN sequence consists of four phases, two of which relate to design, one to instruction, and one to progress monitoring. Unlike the SPIN sequence, the adapted version, shown in Figure 4, is only an instructional process and does not contain a design component. Once the CellF-Monitoring training sequence was developed, the researcher created a training presentation using Microsoft Power Point to facilitate student CellF-Monitoring training (see APPENDIX G CELLF-MONITORING TRAINING PRESENTATION). In order to ensure a high level of training fidelity, the researcher also created and used a training fidelity checklist (see APPENDIX H CELLF-MONITORING TRAINING CHECKLIST).

Each training session began with identifying and defining the target behavior; and brainstorming reasons why being on-task is important. To demonstrate the ability to discriminate between examples and nonexamples of the target behavior, the student participant watched the researcher act out examples and nonexamples of each identifying characteristic of the target behavior and was asked to discriminate between the examples and nonexamples. Then, the student participant had to discriminate between examples and nonexamples of each 
characteristic of the target behavior by demonstrating behaviors of each at the request of the researcher.

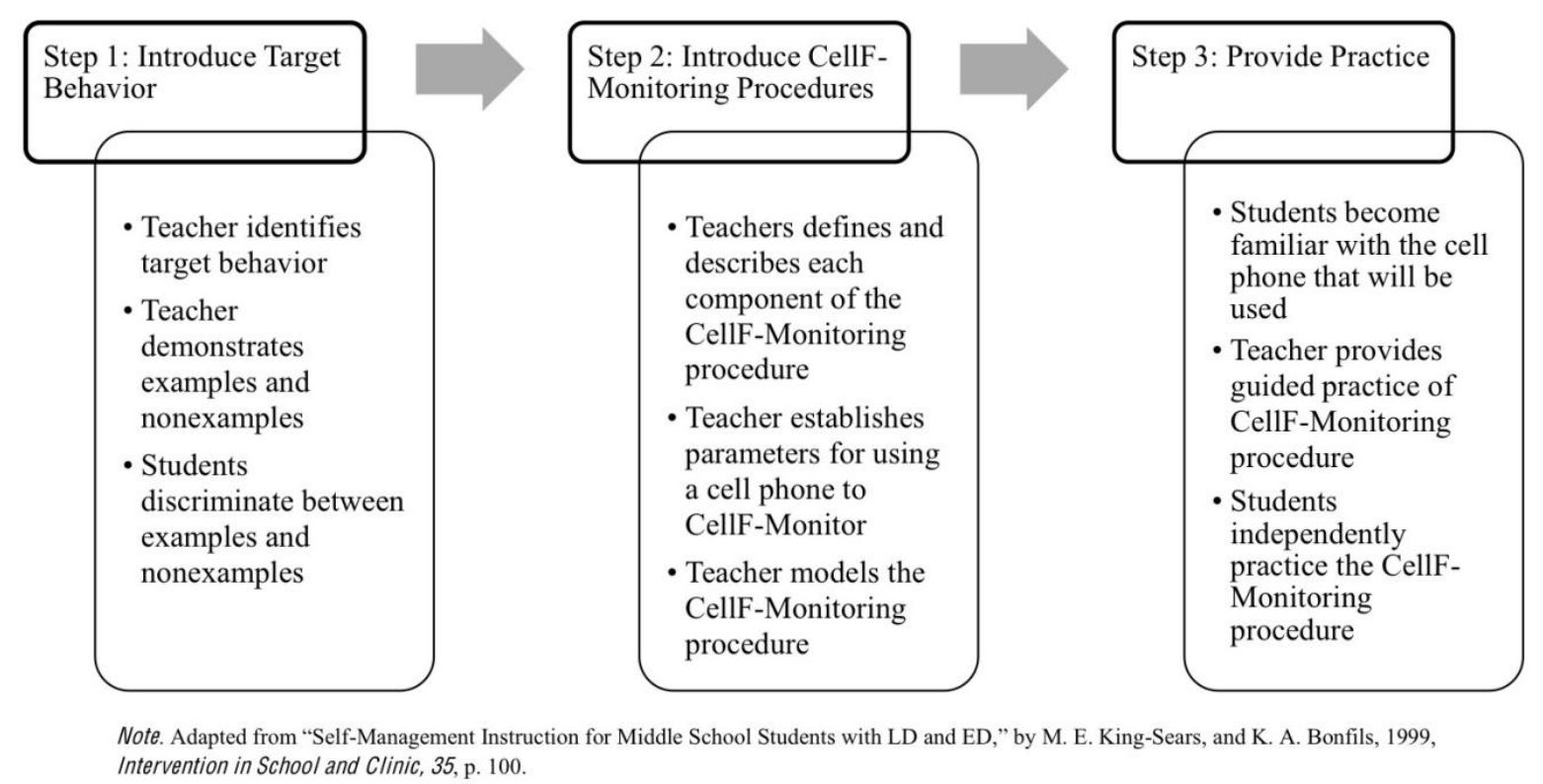

Figure 4. Three Steps to CellF-Monitoring.

Next, the researcher introduced the CellF-Monitoring procedure. First, the researcher defined and explained the purpose of self-monitoring. Second, the researcher described the CellF-Monitoring procedure in detail. Next, the researcher reviewed the parameters for when and how to use the cell phone to CellF-Monitor. For example, each student participant was informed that the cell phone was only to be used for the CellF-Monitoring procedure. Then, the researcher modeled the entire CellF-Monitoring procedure, including the use of the cell phone, through role-play.

Each session concluded with the student participant demonstrating the ability to perform the entire CellF-Monitoring procedure. First, the student participant familiarized himself with 
the intervention cell phone by turning the cell phone on/off, accessing the text message function, opening unread text messages, and responding to text messages with "1", “0”, "Yes", and "No". Second, the researcher provided guided practice by sending the student participant the text message cue and guiding him through the entire CellF-Monitoring procedure. Finally, the researcher provided the student participant with the opportunity for independent practice by sending him a text message cue to initiate the CellF-Monitoring procedure. Opportunities for independent practice were provided as needed for the remainder of the training session.

\section{Intervention}

The intervention was implemented in the experimental classroom the first school day immediately following the student CellF-Monitoring training session. Once the intervention was implemented in the experimental classroom, the student participant got the cell phone from the researcher upon entering the classroom and returned it upon exiting the classroom.

Each student participant used the CellF-Monitoring procedure to self-monitor his own on-task behavior in the experimental classroom. Each student participant received four text message cues at fixed intervals throughout each experimental class. The first text message cue was scheduled to be sent 1-2 minutes before direct observation began and asked "Are you on task?" with a choice of "Yes" or "No" for the response. The second and third text message cues were sent during direct observation from the researcher's cell phone directly to the participants' cell phones at 7 and 14 minutes, respectively. Both text message cues asked "Are you on task?" with a choice of "1 for Yes" and " 0 for No". The fourth text message cue was scheduled to be 
sent 1-2 minutes after direct observation ended and asked "Last time for this class! Are you on task?" with a choice of " 1 for Yes" or " 0 for No". The first and fourth text messages were composed and scheduled using HootSuite and exchanged through Twitter. The questions and response choices had to be different because Twitter does not allow duplication of tweets. In other words, Twitter will not post tweets that are repeated. The text message cues sent during direct observation were the same because repetition of questions and responses was not an issue when sent directly from one cell phone to another using a cell phone's text messaging function. Although the text message cues were sent at fixed intervals there were a few instances when, the time between when the text message cues were sent and the time the student participants received the text message cues varied up to 30 seconds depending on cellular transmission factors that were beyond the control of the researcher.

\section{Post-Intervention Phase}

The study concluded with the social validity questionnaire. The researcher developed and administered a questionnaire to determine the social validity of the CellF-Monitoring procedure. The first part of the questionnaire addressed participants' average use and knowledge of cells phones and text messaging. The second part of the questionnaire was specific to the targeted behavior and the intervention. Additionally, the researcher developed participantspecific questionnaires. For example, a questionnaire was developed for the teacher participants and a questionnaire was developed for the student participants. Teacher participants were asked if the student participants' problem behavior warranted the intervention, if the intervention was 
appropriate for the problem behavior, and if the intervention produced a positive change in the student participants' problem behavior. Student participants were asked what they liked about the intervention, what they disliked about the intervention, if the intervention helped them stay on task, and if they would use the intervention in other classes.

\section{$\underline{\text { Data Analysis }}$}

On-Task Behavior

Direct observation data for student participants' on-task behavior were collected and graphically displayed to provide a detailed summary of (1) the sequence of experimental conditions, (2) the time spent in each condition, (3) the independent and dependent variables, (4) experimental design, and (5) the relationship between the variables (Tawney \& Gast, 1984). According to Kennedy (2005), visual inspection of data is accomplished by "analyzing specific types of patterns in the data display" (p. 196), including level and variability of the data. Level of the data refers to the average of the data within a condition. The level was calculated and reported as the mean. Variability of the data refers to the degree to which individual data points deviate from the trend and was reported as the range.

\section{Social Validity}

Questionnaires were developed to determine the social validity of the CellF-Monitoring procedure. The questionnaires were specific to the teachers' and students' interaction with the intervention procedures. Teacher participants were asked about the social relevance of the target behavior, appropriateness of the procedures in addressing the target behavior, practicality of the 
procedures, effectiveness of the intervention, and their willingness to use the intervention in the future. Student participants were asked what they liked and disliked about the CellF-Monitoring procedure, effectiveness of the intervention, and their willingness to use the intervention in other classes. Participant responses were reviewed and reported in narrative form. 


\title{
CHAPTER FOUR: RESULTS
}

\author{
$\underline{\text { Introduction }}$
}

The purpose of this research study was to determine the effects and social validity of CellF-Monitoring, an innovative self-monitoring procedure. The CellF-Monitoring procedure used cell phone technology to replace traditional cueing and recording procedures that typically incorporate cassette tape players, headphones, pencil, and paper. A multiple-baseline-acrossparticipants design was employed to determine the effects of the CellF-Monitoring procedure on the on-task behavior of students with high incidence disabilities and a questionnaire was developed and administered to determine the social validity of the CellF-Monitoring procedure.

\section{On-Task Behavior}

The first research question sought to determine the affect of CellF-Monitoring on the ontask behavior of students with high incidence disabilities. Data were evaluated using visual inspection. The data paths represented in Figure 5 depict the percentage of intervals that were scored as on-task for each participant in the baseline and intervention phases of the study. Based on visual inspection, the data paths indicate that on-task behavior increased in the intervention phase for both participants. The results are also presented in Table 3 . 


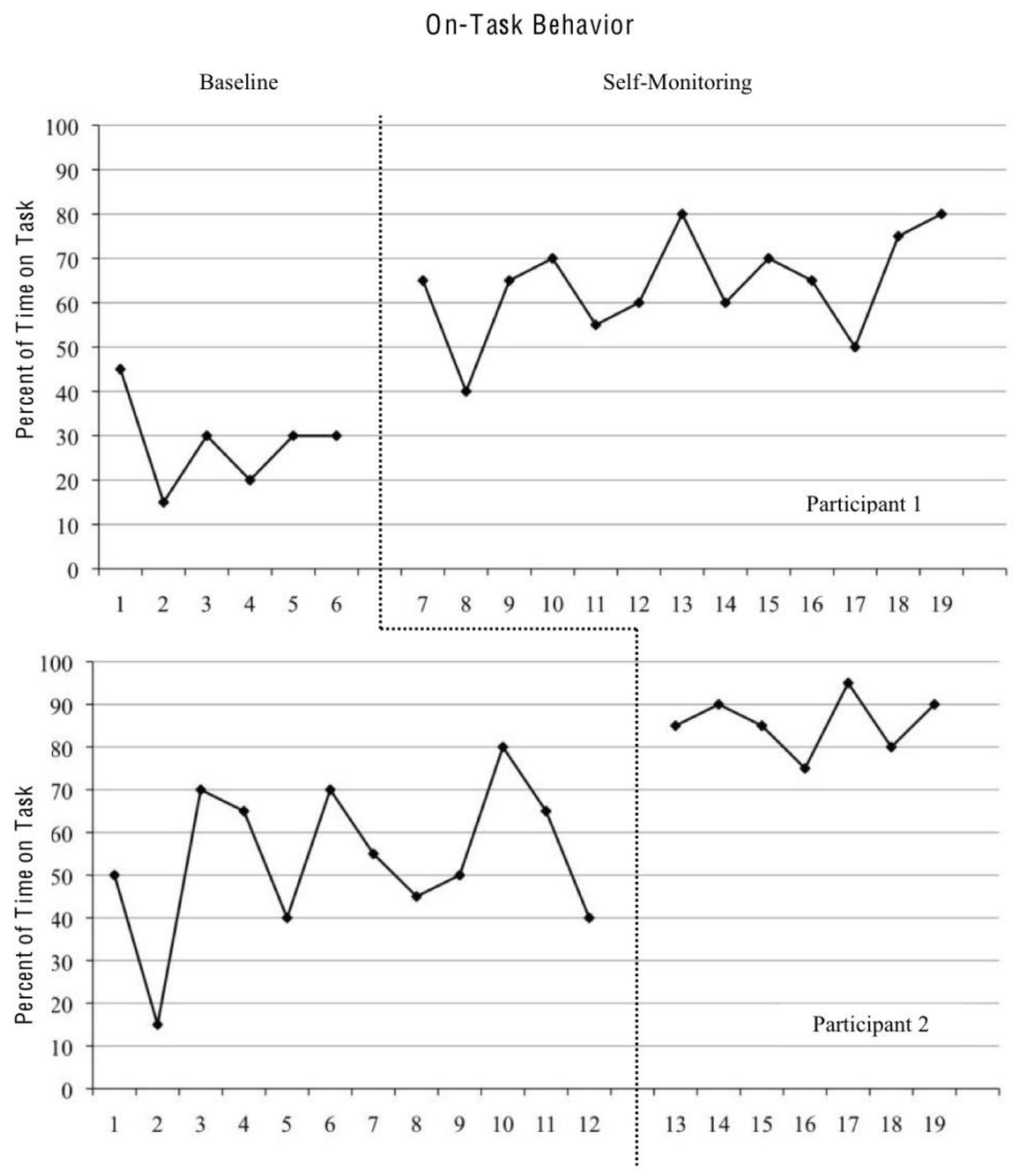

Observation Sessions

Figure 5. Observed On-Task Behavior. 
Table 3. Results

\begin{tabular}{lcccc}
\hline & \multicolumn{2}{c}{ Participant 1 } & \multicolumn{2}{c}{ Participant 2 } \\
\hline & Baseline & Intervention & Baseline & Intervention \\
\hline Mean & 28 & 64 & 53 & 85 \\
Range & 30 & 40 & 65 & 20 \\
\hline
\end{tabular}

The mean, or level, of observed on-task occurrences was calculated and used to compare the pattern of behavior between the baseline and the intervention phases. The total mean for both participants increased from $45 \%$ in the baseline phase to $71 \%$ in the intervention phase. The difference in means between the baseline phase and the intervention phase indicates an increase in participants' time on-task once the intervention was implemented. The first participant, Participant 1, was observed for six school days under baseline conditions and 13 days under intervention conditions. Baseline data demonstrated that Participant 1's mean ontask behavior was $28 \%$ indicating that he was on-task for $28 \%$ of observed intervals. During the intervention phase, his mean on-task behavior was $64 \%$ indicating that Participant 1 was marked as being on task for $64 \%$ of observed intervals once the intervention was implemented. Participant 1's mean on-task behavior in the intervention phase more than doubled from the baseline phase. The second participant, Participant 2, was observed for 12 school days under baseline conditions and seven days under intervention conditions. Baseline data demonstrated that Participant 2's mean on-task behavior was 53\% indicating that he was observed demonstrating on-task behavior for over half of the observation intervals. During the 
intervention phase, Participant 2's mean on-task behavior was 85\%. Participant 2's mean ontask behavior increased from 53\% in the baseline phase to $85 \%$ in the intervention phase.

The range, or variability, of observed on-task occurrences was also calculated and used to measure the spread of occurrences for each phase of the study. The range was calculated by subtracting the lowest percent of total observed on-task occurrences from the highest percent of total observed on-task occurrences for each phase. Participant 1's range increased from 30 in the baseline phase to 40 in the intervention phase. The increase in range indicates that Participant 1's on-task behavior was more stable in the baseline phase than in the intervention phase. Participant 2's range decreased from 65 in the baseline phase to 20 in the intervention phase. The decrease in range indicates that Participant 2's on-task behavior was more stable in the intervention phase than in the baseline phase.

The data demonstrate that the intervention had a positive impact on the on-task behavior of both participants. Participant 1's mean on-task behavior more than doubled from the baseline phase to the intervention phase. Participant 2's mean on-task behavior increased from 53\% to $85 \%$ in the baseline and intervention phases, respectively. Conversely, Participant 2's on-task behavior showed an increase in stability in the experimental phase, whereas Participant 1's behavior became less stable in the intervention phase.

\section{$\underline{\text { Social Validity }}$}

The second research question sought to determine the social validity of the CellFMonitoring procedure. Social validity of the CellF-Monitoring procedure was determined based 
on participant responses to questionnaires. The general and special education teachers had identical responses indicating an overall satisfaction with the CellF-Monitoring procedure. Specifically, the teacher participants reported that the target behavior was socially relevant and warranted the use of the intervention, the intervention was appropriate for the target behavior, and the intervention produced positive effects on the target behavior. Additionally, teacher participants did not feel that the intervention procedures were distracting to other students in the classroom and expressed an interest in using the intervention in the future.

The student participant responses also indicated an overall satisfaction with the CellFMonitoring procedure. Both student participants indicated that they liked the CellF-Monitoring procedure and it helped them stay on task; however, Participant 1 reported that the intervention was distracting at times. Participant 2 expressed excitement at the possibility of using the CellFMonitoring procedure in other classes in the future. Participant 1 expressed uncertainty with future use of the intervention but did not elaborate or explain his apprehension.

\section{$\underline{\text { Inter-Observer Agreement }}$}

According to Kennedy (2005), the current convention is that at least $20 \%$ and preferably $33 \%$ of total observations have inter-observer agreement checks. Five inter-observer agreement checks were made during the course of the current research study, representing approximately $30 \%$ of total observations and exceeding the minimum suggested by Kennedy. Percentages were calculated for occurrence (both observers agreed that the participant was on task), nonoccurrence (both observers agreed that the participant was not on task), and total agreement (overall 
agreement between the observers). Agreement for occurrence was $95 \%$ and agreement for nonoccurrence was 93\%. Overall agreement between both observers was 94\%. All of the interobserver agreement calculations yielded agreement percentages above $80 \%$, which is the standard minimum required for reliability (Kennedy, 2005). Exceeding the standard minimum for reliability indicating (1) minimal variation in the data allowed the researcher to establish a clear pattern of behavior, (2) minimal observer bias, and (3) that the target behavior was operationally defined with clear distinctions between its occurrence and nonoccurrence (Kazdin, 1982; Kennedy, 2005). 


\title{
CHAPTER FIVE: DISCUSSION
}

\author{
$\underline{\text { Introduction }}$
}

The purpose of this chapter is to discuss the results of this research study. The chapter opens with a summary of the findings organized around each of the dependant variables. Next, the unique challenges presented by the study are described followed by the limitations specific to the current study. Finally, the chapter closes with recommendations for future research.

\section{Summary of Findings}

The overall aim of this study was to investigate an innovative method for students with high incidence disabilities to self-monitor their behavior to promote self-regulation and, ultimately, success in inclusive settings. Specifically, the study focused on determining (1) the effects of CellF-Monitoring on the on-task behavior of middle school students with high incidence disabilities in inclusive settings and (2) the social validity of the CellF-Monitoring procedure in inclusive settings. The intervention for this study, CellF-Monitoring was a selfmonitoring procedure that used a cell phone as a cueing and recording device. The study was conducted in an inclusive middle school Language Arts classroom with two participants with high incidence disabilities who received special education services. 


\section{On-Task Behavior}

The results of this study demonstrated a functional relationship between the CellFMonitoring procedure and on-task behavior for middle school students with high incidence disabilities. The total mean for both participants increased from $45 \%$ in the baseline phase to $71 \%$ during the intervention phase indicating that the CellF-Monitoring procedure had a positive influence on the participants' on-task behavior. Results of the current study support prior research findings that self-monitoring produces positive effects on students with high incidence disabilities in inclusive settings (Crum, 2004; DiGangi, Maag, \& Rutherford, 1991; Harris, Friedlander, Saddler, Frizzelle, \& Graham, 2005; Rock, 2005; Rooney, Hallahan, \& Lloyd, 1984). Results also support prior research findings specific to students with ADHD and students with LD. Participant 1's increase of on-task behavior from a mean of $28 \%$ in the baseline phase to a mean of $64 \%$ during the intervention phase supports Harris and colleague's (2005) claim that self-monitoring effectively increases on-task behavior of students with ADHD. Similarly, Participant 2's increase from 53\% during baseline to $85 \%$ during the intervention phases supports prior research concluding that self-monitoring effectively increases on-task behavior of students with LD (DiGangi et al., 1991).

A stabilizing trend for on-task behavior was not as consistent between the two participants. Overall variability of on-task behavior for both students decreased from a range of 65 in the baseline phase to a range of 55 in the intervention phase. Participant 2's range of ontask behavior decreased from 65 during baseline to 20 during the intervention phase indicating a 
stabilizing trend from baseline to the intervention phase. However, Participant 1's on-task behavior range increased from 30 during baseline to 40 during the intervention phase indicating that his on-task behavior was more stable in the baseline phase than it was in the intervention phase. Participant 1's decrease in stabilization of on-task behavior was inconsistent with Harris, Friedlander, Saddler, Frizzelle, and Graham's findings that the on-task behavior of students with ADHD stabilized when self-monitoring procedures were implemented.

\section{Social Validity}

Social validity outcomes from the current study revealed that all of the participants, teachers and students, owned a cell phone at the time of the study. Additionally, both teacher and student participants indicated that they send and/or receive an average of 6-10 text messages each day. Data also revealed an overall satisfaction with the CellF-Monitoring procedure among the teacher and student participants, which were consistent with findings from previous research (Mathes \& Bender, 1997; Shimabukuro, Prater, Jenkins, \& Edelen-Smith, 1999). The practicality of the self-monitoring device used in the CellF-Monitoring procedure was of particular interest and the focus for determining the social validity of the intervention. Teacher participants stated that they liked the intervention procedures and did not view the intervention device as a distraction to the student participants or their peers. Both teacher participants noted improvements in the on-task behavior of both student participants and expressed an interest in using the CellF-Monitoring procedure again in the future. In fact, an informal conversation with the special education teacher participant revealed that she noticed a significant decrease in the 
number of times she had to redirect Participant 1's off-task behavior during the intervention phase.

The student participants indicated that they liked the CellF-Monitoring procedure and it helped them stay on task but had differing opinions about using the intervention in other classes. Participant 1 was not sure if he wanted to use the CellF-Monitoring procedure in other classes because he found the intervention procedures distracting at times. Participant 1's statement that the CellF-Monitoring procedure was sometimes distracting was unexpected, especially since he was able to respond to the text message cues in less than five seconds. The decision to use cell phones as the self-monitoring device was based on the prevalence of adolescents Participant 1's age owning and having cell phones with them at all times. Participant 2, on the other hand, stated that using the CellF-Monitoring procedure was fun and expressed that he would like to use the intervention in all of his classes.

\section{Self-Monitoring and Technology}

To date, only two studies have been conducted examining the effects of self-monitoring procedures that utilize technology, the current study and a study conducted by Gulchak (2008). Results from this study corroborate Gulchak's findings that self-monitoring procedures that incorporate mobile technology produce outcomes similar to the outcomes of traditional selfmonitoring procedures found throughout the research literature. The differences in educational settings, grade level of participants, disability category of participants, and devices used to selfmonitor provide three important insights. First, outcomes of both studies support the notion that 
self-monitoring procedures effectively increase on-task behavior across educational settings and disability categories. Second, results from both studies suggest that self-monitoring procedures updated with technology still produce positive reactive effects on on-task behavior; and third, self-monitoring procedures updated with different types of technology produce similar outcomes.

\section{Accuracy of Recording}

An interesting pattern emerged during data analysis pertaining to recording accuracy that is noteworthy. Recording accuracy has produced fascinating trends throughout the research literature. For example, researchers have asserted that high levels of self-recording accuracy are not required for self-monitoring to influence behavior (Cavalier, Ferretti, \& Hodges, 1997; Lipinski, Black, Nelson, \& Ciminero, 1975; Nelson \& Hayes, 1981) while others state that a minimum level of accuracy is required to produce positive reactive effects (Hallahan, Marshall, \& Lloyd, 1981; McDougall \& Brady, 1995). The contribution of recording accuracy has yet to be determined although recording accuracy data are commonly collected in self-monitoring studies. Although the influence of recording accuracy on the reactive effects of self-monitoring was not formally examined by the current study, results from secondary data warrant further discussion.

For the current study, accuracy of recording was determined by calculating the agreement of occurrence and nonoccurrence of on-task behavior between each participant and the researcher. Participant 2's level of overall recording accuracy was 100\% indicating that his recording of occurrence and nonoccurrence of on-task behavior perfectly matched observation 
data collected by the researcher. Participant 1, on the other hand, had an occurrence recording accuracy of $78 \%$ and a nonoccurrence recording accuracy of only $44 \%$. Despite Participant 1's low level of nonoccurrence accuracy, his mean on-task behavior increased from $28 \%$ during baseline to $64 \%$ during the CellF-Monitoring phase. Data suggest that Participant 1's low level of recording accuracy did not affect the reactivity of the CellF-Monitoring procedures, which support early theory (Nelson \& Hayes, 1981) and research findings (Cavalier, Ferretti, \& Hodges, 1997; Lipinski, Black, Nelson, \& Ciminero, 1975) claiming that high levels of recording accuracy are not required for positive reactive effects of self-monitoring to occur. It is unclear whether Participant 1's low level of nonoccurrence accuracy supports or refutes McDougall and Brady's (1995) assertion that a minimum level of recording accuracy must be achieved before positive reactive effects can occur because what constitutes a minimum level of accuracy has not yet been determined.

\section{$\underline{\text { Unique Challenges }}$}

The unique challenges presented by the current research study offered interesting insights on the use of technology in the classroom but also raised additional questions for the future of technology in the classroom that require careful consideration.

\section{Practical Challenges}

Several practical challenges emerged while designing and conducting the current study. The first challenge was the self-monitoring device itself. Using a cell phone as the intervention device raised questions about confidentiality and maintaining control over how the device would 
be used by participants in the classroom. Cell phones were chosen as the intervention device over other mobile technology devices because of their prevalence among students in secondary settings. Although allowing participants to use their own cell phones appeared more authentic in demonstrating the ubiquity of cell phones, the researcher decided to provide cell phones to the participants to minimize inappropriate use of the device by maintaining how and where the device was used by the participant.

The second and most significant challenge in conducting the current study was obtaining district approval to conduct the study in a public middle school. District personnel granted permission after two separate requests to conduct research. It was evident to the researcher that the first research request was denied solely based on the intervention device being a cell phone without consideration to any of the safeguards that were clearly outlined in anticipation of such a reaction by district personnel, school administrators, and classroom teachers. Although the request was denied, district personnel listed their concerns for the use of a cell phone as the intervention device and suggestions for revising the study to resubmit the request. The researcher reformatted the research request to make the same safeguards for the use of the cell phone as the intervention device that were in the first request more visible and reworded to specifically address each of the concerns listed by district personnel. Thus, the second request to conduct research in a public middle school was approved. The entire approval process took over six weeks - an extended timeline that was not anticipated by the researcher. 


\section{Technical Challenges}

The current study assessed the effects of CellF-Monitoring, a self-monitoring procedure that utilized a cell phone as the cueing and recording device. As with any intervention that includes a technology component, using a cell phone as the cueing and recording device for selfmonitoring was laced with various technical challenges. The first technical challenge was finding a way to automate the text message cues that would work across cell phones and networks to ensure that the practicality of the intervention and replicability of the study were not compromised in any way. The researcher conducted an internet search for a free universal cell phone or computer application that enabled automated text messages to be sent to cell phones. Although several were found, replies could not be sent directly from the receiving cell phone, which was required for the recording component of the intervention. Only one free application was found that allowed messages to be scheduled for delivery at specified date and time. HootSuite is a free computer application that allows registered users to compose and schedule messages. However, the scheduled messages cannot be sent directly from the application to a cell phone. The scheduling function of the application is designed to send updates to a Twitter account at pre-determined dates and times. Twitter, a free social networking application, includes a mobile option that allows registered users to post updates to their Twitter account and receive updates posted by other Twitter users selected by the user. The researcher decided to use HootSuite as the platform to compose and schedule the text message cues and Twitter as the 
platform through which text message cues and replies would be exchanged between the researcher and participants.

The second technical challenge was successfully executing the process of (1) composing, scheduling, and sending text message cues and (2) receiving and replying to text message cues. First, the researcher created HootSuite and Twitter accounts and enabled Twitter mobile options that were linked to intervention cell phones. Second, the researcher practiced the entire intervention procedure multiple times with each intervention cell phone. It was through practicing the intervention procedures that the researcher learned that Twitter does not allow duplication of updates. In other words, Twitter does not allow a series of posts that ask the same question (e.g., Are you on task?). Therefore, the language of each text message cue and the choices provided for participant responses had to be alternated for successful execution of the cueing and recording process.

\section{Social Validity Challenges}

Self-monitoring is highlighted throughout the research literature as a socially valid intervention that is effective in changing behavior. Preserving the benefits that make selfmonitoring a practical intervention while attempting to include a digital device to enhance its procedures was challenging. A self-monitoring procedure that utilized a cell phone as the cueing and recording device could not be more complicated or time consuming than traditional selfmonitoring procedures. Since traditional cueing procedures use pre-recorded audio tones on a cassette tape that typically only need to be developed once, the process for composing and 
scheduling the text message cues had to be just as efficient. Additionally, recording procedures that use a cell phone had to be comparable to traditional procedures that typically employ pencil and paper for recording. As such, the researcher outlined a process to facilitate the cueing and recording procedures that required the least amount of time to implement and the least amount of effort to manage. The process requires the teacher to create HootSuite and Twitter accounts that may seem complicated and daunting to a teacher with limited computer skills or minimal social networking experience. However, once the initial set-up is completed, managing the intervention is less complicated.

\section{$\underline{\text { Limitations }}$}

Although the CellF-Monitoring procedure appears to produce positive effects on the ontask behavior of students with high incidence disabilities, there were several limitations to the study. The limitations included (a) the low number of replications, (b) the small sample size, (c) the lack of teacher involvement, and (d) that participants used cell phones that were provided by the researcher.

The first limitation of the study was the low number of replicated effects of the intervention. Multiple-baseline designs demonstrate the effectiveness of an intervention by replicating the effects of an intervention across multiple settings, behaviors, or participants (Kazdin, 1982; Kennedy, 2005; Tawney \& Gast, 1984). Although one replication is sufficient to demonstrate the effectiveness of an intervention (Kennedy, 2005), Tawney and Gast (1984) state that at least two replications are required to conclude that an intervention is effective. The 
current study only replicated the effects of the intervention once making it difficult to attest to the effectiveness of the intervention.

Second, the small sample size inherent in single subject research limits generalization and external validity (Kazdin, 1982). For example, it is unknown whether the findings of the current study could be replicated with students other than those with LD and ADHD in a middle school inclusive Language Arts classroom. However, with findings from prior research (Gulchak, 2008), one could reasonably assume that self-monitoring procedures that utilize mobile technology may produce positive effects on the on-task behavior of students with high incidence disabilities in elementary self-contained settings and middle school inclusive settings.

A third limitation of the current study is that the classroom teacher was not involved in the training or implementation of the intervention limiting social validity findings. According to Horner et al. (2005), for an intervention to be socially valid, teachers must be able to implement the intervention procedures with a high level of validity. However, in this study, the researcher taught the student participants the self-monitoring procedures, composed and scheduled the text message cues, and collected all of the behavioral data. The reason for extensive researchercontrol was to ensure a high level of treatment fidelity. The focus of the study was the effectiveness of an innovative self-monitoring procedure on student behavior so a high level of treatment fidelity was required and extraneous variables kept to a minimum in order for the results to be reported with confidence. 
Finally, the student participants used cell phones that were provided by the researcher. The premise of using cell phones as a self-monitoring device is its prevalence among middle school students. The availability of cell phones eliminates the need for teachers to provide materials to implement the intervention and strengthens the social validity of the intervention. However, to obtain permission from the school district to conduct the study, the researcher had to provide the cell phones to the students. The cell phones provided to the students did not contain any contact information or applications, which would normally be on students' personal cell phones. As such, it is unknown if a student using his or her own cell phone for the CellFMonitoring procedure would be more of a distraction than an intervention device.

\section{$\underline{\text { Suggestions for Future Research }}$}

The limitations previously discussed provide many opportunities for future research. First, replication is necessary to validate the effectiveness of the CellF-Monitoring procedure. As stated earlier, effects of the CellF-Monitoring procedure were only replicated once with an additional participant in the same setting. According to Horner et al. (2005), one of the five criteria of single subject research that needs to be met for a practice to be considered evidencebased is replication of a functional relationship across subjects, researchers, and settings.

Second, future research should also determine the practicality of classroom teachers implementing the intervention to strengthen the social validity of the CellF-Monitoring procedure. Implementation should include completing the initial set-up for the cueing and recording, conducting the student training, and implementing and maintaining the intervention in 
the classroom. High levels of fidelity are especially important for the initial set-up process, which may seem complicated or confusing to teachers with a limited technology skill set. By obtaining information on teachers' level of comfort in working with technology, researchers may also determine if teachers' level of comfort with technology influences the reactive effects of the CellF-Monitoring procedure.

Finally, research is necessary to determine the practicality of students using personal cell phones for the CellF-Monitoring procedure. The attraction of the CellF-Monitoring procedure is that the device needed for implementation is prevalent among middle school students. In theory, teachers can implement the intervention without the need to create or purchase additional materials. However, it is not known if the use of students' personal cell phones will make the CellF-Monitoring procedure more of a distraction than an effective intervention.

\section{Cell Phones and Education}

The challenge of conducting research on and using cell phones in educational settings is not without reason. Although cell phones are considered miniature computers, they are viewed as social toys and are banned from classrooms in $69 \%$ of schools across the country (Common Sense Media, 2010). Disruption, cheating, and dissemination of inappropriate pictures and text messages among students are consistently cited as reasons for banning of cell phones from classrooms (Kolb, 2009; McNeal \& van't Hooft, 2006). Are the benefits of using cell phones in the classroom given as much consideration as reasons for not using them in the classroom? Have educational stakeholders taken into consideration that cell phones allow students to gather, 
access, and process information inside and outside of the classroom? Or, that because of their relatively low cost and prevalence among students regardless of race/ethnicity and social economic status, cell phones can help level the digital playing field? Sure, cell phones may be a distraction at times and some students may use them inappropriately; but can't the same thing happen with a pencil? So, why not develop policies and procedures for appropriate use of cell phones in the classroom instead of policies and procedures that prohibit their use in classrooms? Wouldn't educators' time be better spent on finding authentic and creative ways to use cell phones in the classroom rather than fighting cell phone use?

The battle over cell phones in the classroom is much larger than it appears. The resistance to allowing cell phones in the classroom leads to a question about the use of technology in education on an even grander scale. If the goal of education is to prepare students

for a competitive $21^{\text {st }}$ century global market, then why are the skills and tools necessary for their success prohibited in classrooms? It is time for the field of education to respond differently to new and innovative technology by becoming better consumers of research and taking into consideration any benefits of innovative technology prior to labeling it as a detriment to education.

\section{$\underline{\text { Conclusion }}$}

Even with the limitations and the need for future research, the results of the current study suggest that the CellF-Monitoring procedure produced positive effects on the on-task behavior of the students in this study. The results of this study further validate the use of cell phones as a 
self-monitoring device while maintaining the positive reactive effects documented throughout the research literature. Additionally, research demonstrating a practical research-based use for cell phones in educational settings may prompt educational stakeholders to move away from viewing cell phones as social toys and move towards viewing cell phones as what they really are - powerful mobile computers. 


$$
-
$$


University of Central Florida Institutional Review Board Office of Research \& Commercialization

12201 Research Parkway, Suite 501

Central

Orlando, Florida 32826-3246

Telephone: 407-823-2901 or 407-882-2276

www.research.ucf.edu/compliance/irb.html

\section{Approval of Exempt Human Research}

From:

UCF Institutional Review Board \#1

FWA00000351, IRB00001138

To:

Pena Bedesem

Date:

April 01, 2010

Dear Researcher:

On 04/01/2010, the IRB approved the following modification - revision to consent documents to reflect changes in participant eligibility criteria and estimated time-line for the study - to human participant research that is exempt from regulation:

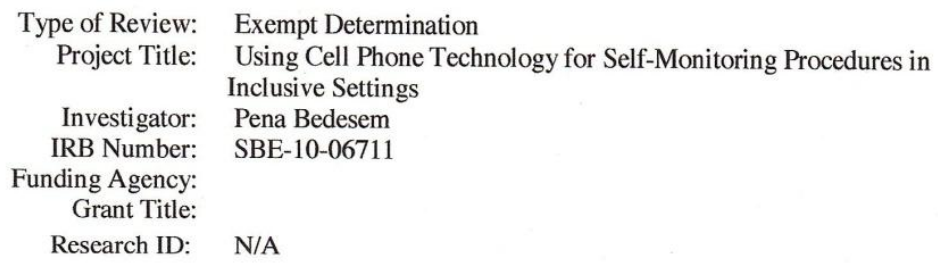

This determination applies only to the activities described in the IRB submission and does not apply should any changes be made. If changes are made and there are questions about whether these changes affect the exempt status of the human research, please contact the IRB. When you have completed your research, please submit a Study Closure request in iRIS so that IRB records will be accurate.

In the conduct of this research, you are responsible to follow the requirements of the Investigator Manual.

On behalf of Joseph Bielitzki, DVM, UCF IRB Chair, this letter is signed by:

Signature applied by Joanne Muratori on 04/01/2010 04:58:37 PM EST

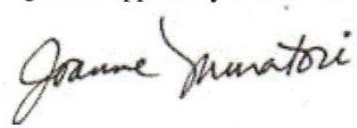

IRB Coordinator 
APPENDIX B

TEACHER CONSENT DOCUMENT

3 


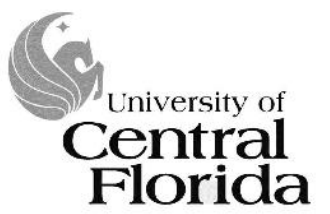

\section{EXPLANATION OF RESEARCH}

Title of Project: Using Cell Phone Technology for Self-Monitoring Procedures in Inclusive Settings

Principal Investigator: Peña Lasiste Bedesem

Other Investigators: Jacqueline Rodriguez

Faculty Supervisor: Lee Cross, $\mathrm{PhD}$

You have been chosen to participate in a study that is being conducted for research in conjunction with the University of Central Florida, College of Education. Your identifying information has not been shared in any way with the researcher at this time. You were chosen because you meet the criteria for this study and are being offered the opportunity to participate.

The purpose of the research is to evaluate the effects and practicality of a self-monitoring procedure that utilizes cell phones for cueing and recording on the on-task behavior of students in inclusive settings.

With your consent, student in your classroom will learn how to self-monitor his/her on-task behavior using a self-monitoring procedure that uses a cell phone. The researcher will provide the cell phone and take responsibility for any charges associated with using the cell phone as part of the intervention. At the end of the study, you will be asked to complete a social validity questionnaire to evaluate the practicality of using a cell phone to self-monitor behavior in inclusive classrooms, which will take less than 30 minutes to complete and the entire research study is expected to take 6-8 weeks.

Your name, the names of your students, and the name of your school will be kept confidential and will not be used in any report, analysis, or publication. All identifying information will be replaced with alternate names or codes. You have the right to refuse to participate and stop participating in this research study at any time.

Study contact for questions about the study or to report a problem: If you have questions, concerns, or complaints: Peña L. Bedesem, Doctoral Candidate, Exceptional Student Education, College of Education, (407) 928-2598 or by email at pbedesem@knights.ucf.edu; or Dr. Lee Cross, Faculty Supervisor, Department of Children, Family and Community Sciences at (407) 823-2233 or by email at lcross@mail.ucf.edu.

IRB contact about your rights in the study or to report a complaint: Research at the University of Central Florida involving human participants is carried out under the oversight of the Institutional Review Board (UCF IRB). This research has been reviewed and approved by the IRB. For information about the rights of people who take part in research, please contact: Institutional Review Board, University of Central Florida, Office of Research \& Commercialization, 12201 Research Parkway, Suite 501, Orlando, FL 32826-3246 or by telephone at (407) 823-2901. 


\section{APPENDIX C \\ PARENT CONSENT DOCUMENT}




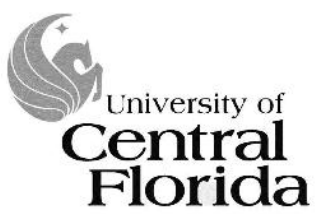

\section{EXPLANATION OF RESEARCH}

Title of Project: Using Cell Phone Technology for Self-Monitoring Procedures in Inclusive Settings

Principal Investigator: Peña Lasiste Bedesem

Other Investigators: Jacqueline Rodriguez

Faculty Supervisor: Lee Cross, $\mathrm{PhD}$

Your child has been chosen to participate in a study that is being conducted for research in conjunction with the University of Central Florida, College of Education. Your child's identifying information has not been shared in any way with the researcher at this time. Your child was chosen because he/she meets the criteria for this study and you, as parent, are being offered the opportunity to have your child participate. Students who meet eligibility criteria for participant in the research study are those who are already identified as having an emotional or behavioral disorder or at risk for being identified as having an emotional or behavioral disorder as defined by the state of Florida guidelines.

The purpose of the research is to evaluate the effects and practicality of a self-monitoring procedure that utilizes cell phones for cueing and recording on the on-task behavior of students in inclusive settings.

With your consent, your child will learn how to self-monitor his/her on-task behavior in three inclusive academic classrooms using a self-monitoring procedure that uses a cell phone. The researcher will provide the cell phone and take responsibility for any charges associated with using the cell phone as part of the intervention. At the end of the study, you and your child will be asked to complete a social validity questionnaire to evaluate the practicality of using a cell phone to self-monitor behavior in inclusive classrooms, which will take less than 30 minutes to complete and the entire research study is expected to take 6-8 weeks in the designated classrooms.

Your child's name, the names of his/her teachers, and the name of your child's school will be kept confidential and will not be used in any report, analysis, or publication. All identifying information will be replaced with alternate names or codes.

Your child will be allowed the right to refuse to participate and stop participating in this research study at any time. Your child will be reminded of this prior to the self-monitoring training and prior to beginning the self-monitoring procedure in each classroom.

Study contact for questions about the study or to report a problem: If you have questions, concerns, or complaints: Peña L. Bedesem, Doctoral Candidate, Exceptional Student Education, College of Education, (407) 928-2598 or by email at pbedesem@knights.ucf.edu; or Dr. Lee Cross, Faculty Supervisor, Department of Children, Family and Community Sciences at (407) 823-2233 or by email at lcross@mail.ucf.edu. 
IRB Protocol No.

Date:

IRB contact about your rights in the study or to report a complaint: Research at the University of

Central Florida involving human participants is carried out under the oversight of the Institutional Review Board (UCF IRB). This research has been reviewed and approved by the IRB. For information about the rights of people who take part in research, please contact: Institutional Review Board, University of Central Florida, Office of Research \& Commercialization, 12201 Research Parkway, Suite 501, Orlando, FL 32826-3246 or by telephone at (407) 823-2901.

Name of student:

Parent's name (printed):

Parent's signature:

Date: 
APPENDIX D

SOCIAL VALIDITY QUESTIONNAIRES

8 
Social Validity Questionnaire

(Teacher)

\begin{tabular}{|c|c|c|c|c|}
\hline \multirow{2}{*}{\multicolumn{2}{|c|}{ 1. Do you own a cell phone? }} & Yes & & No \\
\hline & & $\square$ & & $\square$ \\
\hline \multirow{2}{*}{\multicolumn{2}{|c|}{ 2. If yes, do you use the text message function of your phone? }} & Yes & & No \\
\hline & & $\square$ & & $\square$ \\
\hline \multirow{2}{*}{\multicolumn{2}{|c|}{$\begin{array}{l}\text { 3. If yes, do you use the text message function of your cell phone at least } \\
\text { once a day? }\end{array}$}} & Yes & & No \\
\hline & & $\square$ & & $\square$ \\
\hline \multirow{2}{*}{$\begin{array}{l}\text { 4. If yes, estimate the number of text messages you send on } \\
\text { average each day. }\end{array}$} & $1-5 \quad 6-10$ & $11-15$ & $16-20$ & $21+$ \\
\hline & $\square \quad \square$ & $\square$ & $\square$ & $\square$ \\
\hline \multirow{2}{*}{\multicolumn{2}{|c|}{$\begin{array}{l}\text { 5. Self-monitoring that utilizes a cell phone would be an acceptable } \\
\text { intervention to increase on-task behavior. }\end{array}$}} & Yes & & No \\
\hline & & $\square$ & & $\square$ \\
\hline \multirow{2}{*}{\multicolumn{2}{|c|}{ 6. I like the procedures used in the intervention. }} & Yes & & No \\
\hline & & $\square$ & & $\square$ \\
\hline \multirow{2}{*}{\multicolumn{2}{|c|}{ 7. The student's behavior problem warranted the use of this intervention. }} & Yes & & No \\
\hline & & $\square$ & & $\square$ \\
\hline \multirow{2}{*}{\multicolumn{2}{|c|}{ 8. Using the cell phone as the intervention device did not distract the student. }} & Yes & & No \\
\hline & & $\square$ & & $\square$ \\
\hline \multirow{2}{*}{\multicolumn{2}{|c|}{$\begin{array}{l}\text { 9. The student using the cell phone as the intervention device did not distract } \\
\text { other students in the classroom. }\end{array}$}} & Yes & & No \\
\hline & & $\square$ & & $\square$ \\
\hline \multirow{2}{*}{\multicolumn{2}{|c|}{$\begin{array}{l}\text { 10. Most teachers would find this intervention appropriate for students with } \\
\text { challenging behaviors in inclusive settings. }\end{array}$}} & Yes & & No \\
\hline & & $\square$ & & $\square$ \\
\hline \multirow{2}{*}{\multicolumn{2}{|c|}{ 11. I would suggest the use of this intervention to other teachers. }} & Yes & & No \\
\hline & & $\square$ & & $\square$ \\
\hline \multirow{2}{*}{\multicolumn{2}{|c|}{$\begin{array}{l}\text { 12. Most teachers would find this intervention appropriate for increasing on- } \\
\text { task behavior. }\end{array}$}} & Yes & & No \\
\hline & & $\square$ & & $\square$ \\
\hline \multirow{2}{*}{\multicolumn{2}{|c|}{ 13. I would be willing to use this intervention in the classroom setting. }} & Yes & & No \\
\hline & & $\square$ & & $\square$ \\
\hline \multirow{2}{*}{\multicolumn{2}{|c|}{ 14. Overall, the intervention was beneficial for the student. }} & Yes & & No \\
\hline & & $\square$ & & $\square$ \\
\hline
\end{tabular}


Social Validity Questionnaire

(Student)

1. Do you own a cell phone? $\quad$ Yes No

\begin{tabular}{lrr} 
& $\square$ & $\square \quad$ No \\
\hline 2. If yes, do you use the text message function of your phone? & $\square$ & $\square \quad$ No \\
\hline $\begin{array}{l}\text { 3. If yes, do you use the text message function of your cell phone at least once a } \\
\text { day? }\end{array}$ & Yes & $\square$ \\
\hline $\begin{array}{l}\text { If yes, estimate the number of text messages you send on average } \\
\text { each day. }\end{array}$ & $1-5$ & $6-10 \quad 11-15 \quad 16-20 \quad 21+$ \\
\hline
\end{tabular}

5. What did you like about using the cell phone to self-monitor your behavior?

6. What did you dislike about using the cell phone to self-monitor your behavior? 
APPENDIX E

OBSERVATION RECORDING SHEET 


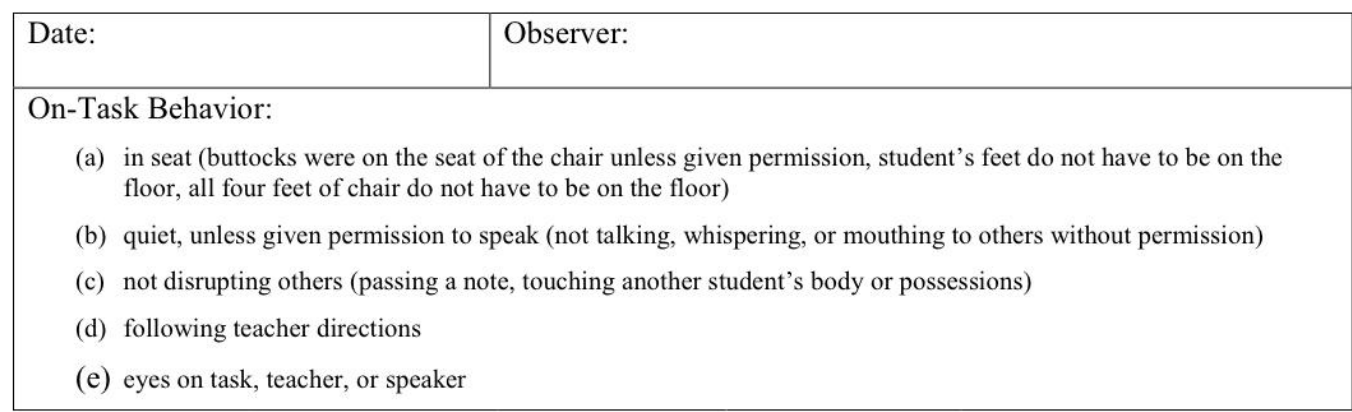

$$
\begin{gathered}
\mathrm{X} / \mathrm{Y}=\text { Interval during which text message cue was sent } \\
\mathrm{X}=\text { Researcher Observation } \\
\mathrm{Y}=\text { Student Participant Response }
\end{gathered}
$$

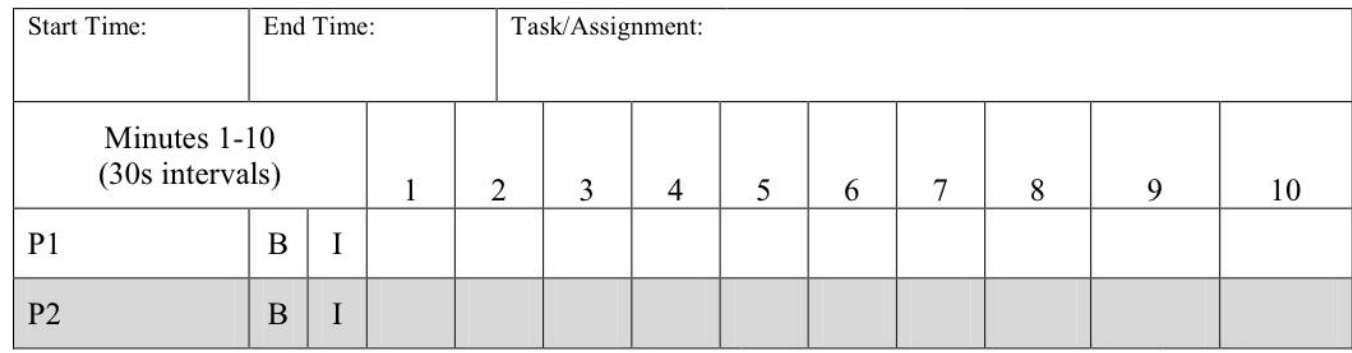

\begin{tabular}{|l|c|c|c|c|c|c|c|c|c|c|c|c|}
\hline \multicolumn{3}{|c|}{ Minutes 11-20 } & 11 & 12 & 13 & 14 & 15 & 16 & 17 & 18 & 19 & 20 \\
\hline P1 & B & I & & & & & & & & & & \\
\hline P2 & B & I & & & & & & & & & & \\
\hline
\end{tabular}

\begin{tabular}{|l|l|l|l|l|}
\cline { 2 - 5 } \multicolumn{1}{c|}{} & Total \# of 1's & Total \# of 0's & $\begin{array}{c}\text { Percent of Time } \\
\text { On Task }\end{array}$ & $\begin{array}{c}\text { Student Part/Researcher } \\
\text { Agreement }\end{array}$ \\
\hline P1 & & & & \\
\hline P2 & & & & \\
\hline
\end{tabular}


APPENDIX F

\section{TEACHER PROTOCOLS}




\section{Specific Teacher Protocols During Each Experimental Class}

Please DO:

1. Conduct class as usual

2. Continue with any classroom management plan established prior to the research study

Please DO NOT:

1. Prompt the participant more than usual to get on-task or stay on-task

2. Provide specific praise or external reinforcement above and beyond what was provided to the participant during baseline or generally provided to other students in the class

3. Dismiss the participant from any classroom management plan established prior to the research study

4. Exclude the student from disciplinary action due to inappropriate classroom behavior

5. Lower behavioral or academic expectations for the participant

6. Use the intervention and/or device as reinforcers 


\section{APPENDIX G CELLF-MONITORING TRAINING PRESENTATION}

\section{Three Steps to CellF-Monitoring}

Ms. Bedesem

University of Central Florida \& Jackson Middle School, Orange County Public Schools

\section{Three Steps to CellF-Monitoring: Step 1}

The target behavior is on-task behavior

What does on-task behavior look and/or sound like?

1. In your seat

2. Quiet

3. Not disrupting others

4. Following teacher directions

5. Eyes on the assignment, teacher, or speaker 


\section{Three Steps to CellF-Monitoring: Step 1}

Why do I think being on task is important?

1. To get good grades!

2. To learn valuable information!

Why do you think being on task is important?

$3 / 11 / 10$

Three Steps to CellF-Monitoring: Step 2 


\title{
Three Steps to CellF-Monitoring: Step 2
}

\author{
Cell Phone Rules
}

1. Keep cell phone on vibrate mode

2. Do not take cell phone out of pocket/desk unless text message cue is received

3. Reply to text message cue as quickly as possible ( 5 seconds or less)

4. Return cell phone to pocket/desk immediately after responding to text message cue

5. Do not flaunt or acknowledge that you are able to use the cell phone in class/school

$3 / 11 / 10$

\section{Three Steps to CellF-Monitoring: Step 2}

Now, I am going to show you the entire CellF-Monitoring procedure!

Pay special attention to

1. My phone being on vibrate

2. How quickly I read and respond to the text message cue 


\section{Three Steps to CellF-Monitoring: Step 3}

Now you get to 'play' with the cell phone and practice the CellF-Monitoring procedure

1. You will wait to receive a new text message

2. You will read and respond to the text message

3. You will repeat the procedure when instructed

$3 / 11 / 10$

\section{Three Steps to CellF-Monitoring: Step 3}

1. Turn the phone on, off, and then on again

2. Put the cell phone on vibrate mode

3. Put the cell phone in your pocket

4. Once you receive the text message, go to the text message inbox

5. Open and read the unread text message

6. Reply with a " 1 " to the text message

7. Wait for a new text message to be received

8. Repeat steps 3 and 4

9. Reply with a " 0 " to the text message

$3 / 11 / 10$ 


Congratulations,
you are now
ready to
CellF-Monitor
your own
behavior!!
3/11100




\section{APPENDIX H \\ CELLF-MONITORING TRAINING CHECKLIST}




\section{Three Steps to CellF-Monitoring Training Checklist}

\section{Step 1: Introduce Target Behavior}

Identify the target behavior

Define the target behavior

Demonstrate examples and nonexamples of the target behavior

Provide an example of why the target behavior is important

Have the student brainstorm 2-4 additional reasons the target behavior is importe

\section{Step 2: Introduce CellF-Monitoring Procedure}

Define the purpose of each component of the self-monitoring procedure
$\circ$ Cue
- Assess
$\circ$ Record

Explain how the cell phone is used in the CellF-Monitoring procedure
- Text Message Cue
- Text Message Reply to Record

Explain Cell Phone Rules

\section{Step 3: Provide Practice}

Model the entire CellF-Monitoring procedure

Allow students to 'play' with the cell phone

- Turn the cell phone off/on

- Put the cell phone on vibrate mode

- Access text message inbox

- Open and read an unread text message cue

- Reply to a text message cue

Allow students to practice the entire CellF-Monitoring procedure

- Guided practice

- Independent practice 


\section{REFERENCES}

Anderson, A. \& Wheldall, K. (2004). The who, what, where, when, and why of self-monitoring of student behaviour. Australasian Journal of Special Education, 28(2), 30-64.

Baer, D. M., Wolf, M. M., \& Risley, T. R. (1968). Some current dimensions of applied behavior analysis. Journal of Applied Behavior Analysis, 1(1), 91-97.

Bahr, M. W., Fuchs, D., Fuchs, L. S., Fernstrom, P., \& Stecker, P. M. (1993). Effectiveness of student versus teacher monitoring during prereferral intervention. Exceptionality, 4(1), 17-30.

Ballard, K. D., \& Glynn, T. (1975). Behavioral self-management in story writing with elementary school children. Journal of Applied Behavior Analysis, 8(4), 387-398.

Barlow, D. H., \& Hayes, S. C. (1979). Alternating treatments design: One strategy for comparing the effects of two treatments in a single subject. Journal of Applied Behavior Analysis, $12,199-210$.

Broden, M., Hall, R. V., \& Mitts, B. (1971). The effects of self-recording on the classroom behavior of two eighth-grade students. Journal of Applied Behavior Analysis, 4(3), 191199.

Cavalier, A. R., Ferretti, R. P., \& Hodges, A. E. (1997). Self-management within a classroom token economy for students with learning disabilities. Research in Developmental Disabilities, 18(3), 167-178.

Cortiella, C. (2006). NCLB and IDEA: What parents of students with disabilities need to know and do. Minneapolis, MN: University of Minnesota, National Center on Educational Outcomes. 
Crum, C. F. (2004). Using a cognitive-behavioral modification strategy to increase on-task behavior of a student with a behavior disorder. Intervention in School and Clinic, 39(5), 305-309.

Dalton, T., Martella, R. C., \& Marchand-Martella, N. E. (1999). The effects of a selfmanagement program in reducing off-task behavior. Journal of Behavioral Education, 9(3/4), 157-176.

Data Accountability Center, (2009). Individuals with disabilities education act (IDEA) data [Data file]. Retrieved from http://ideadata.org/

DiGangi, S. A., Maag, J. W., \& Rutherford, R. B. (1991). Self-graphing of on-task behavior: Enhancing the reactive effects of self-monitoring on on-task behavior and academic performance. Learning Disability Quarterly, 14(3), 221-230.

Dunlap, G., Clarke, S., Jackson, M., Wright, S., Ramos, E., \& Brinson, S. (1995). Selfmonitoring of classroom behaviors with students exhibiting emotional and behavioral challenges. School Psychology Quarterly, 10(2), 165-177.

Fitzpatrick, M. \& Knowlton, E. (2009). Bringing evidence-based self-directed intervention practices to the trenches for students with emotional and behavioral disorders. Preventing School Failure, 53(4), 253-266.

Florida Department of Education. (2010). 2010 LEA Profile: Orange County. Retrieved from http://www.fldoe.org/ese/pdf/2010lea/Orange.pdf

Freeman, K. A., \& Dexter-Mazza, E. T. (2004). Using self-monitoring with an adolescent with disruptive classroom behavior: Preliminary analysis of the role of adult feedback. Behavior Modification, 28(3), 402-419.

Friend, M., \& Cook, L. (2003). Interactions: Collaboration skills for school professionals $\left(4^{\text {th }}\right.$ ed.). New York: Longman.

Glynn, E. L., \& Thomas, J. D. (1974). Effect of cueing on self-control of classroom behavior. Journal of Applied Behavior Analysis, 7(2), 299-306.

Glynn, E. L., Thomas, J. D., \& Shee, S. M. (1973). Behavioral self-control of on-task behavior in an elementary classroom. Journal of Applied Behavior Analysis, 6(1), 105-113. 
Gottman, J. M., \& McFall, R. M. (1972). Self-monitoring effects in a program for potential high school dropouts: A time-series analysis. Journal of Consulting and Clinical Psychology, 39(2), 273-281.

Gresham, F. M., \& MacMillan, D. L. (1997). Social competence and affective characteristics of students with mild disabilities. Review of Educational Research, 67(4), 377-415.

Gulchak, D. J. (2008). Using a mobile handheld computer to teach a student with an emotional and behavioral disorder to self-monitor attention. Education and Treatment of Children, 31(4), 567-581.

Gunter, P. L., Venn, M. L., Patrick, J., Miller, K. A., \& Kelly, L. (2003). Efficacy of using momentary time samples to determine on-task behavior of students with emotional/behavioral disorders. Education and Treatment of Children, 26(4), 400-412.

Hallahan, D. P., \& Kauffman, J. M. (1977). Labels, categories, behaviors: ED, LD, and EMR reconsidered. Journal of Special Education, 11(2), 139-149.

Hallahan, D. P., Lloyd, J., Kosiewicz, M. M., Kauffman, J. M., \& Graves, A. W. (1979). Selfmonitoring of attention as a treatment for a learning disabled boy's off-task behavior. Learning Disability Quarterly, 2(3), 24-32.

Hallahan, D. P., Marshall, K. J., \& Lloyd, J. W. (1981). Self-recording during group instruction: Effects on attention to task. Learning Disability Quarterly, 4(4), 407-413.

Hardman, M. L., \& Dawson, S. (2008). The impact of federal public policy on curriculum and instruction for students with disabilities in the general classroom. Preventing School Failure, 52(2), 5-11.

Harris, K R., Friedlander, B. D., Saddler, B., Frizzelle, R., \& Graham, S. (2005). Self-monitoring of attention versus self-monitoring of academic performance: Effects among students with ADHD in the general education classroom. The Journal of Special Education, 39(3), 145-156.

Harris, K. R., Graham, S., Reid, R., McElroy, K., \& Hamby, R. (1994). Self-monitoring of attention versus self-monitoring of performance: Replication and cross-task comparison studies. Learning Disability Quarterly, 17, 121-139.

Hayes, S. C. \& Nelson, R. O. (1983). Similar reactivity produced by external cues and selfmonitoring. Behavior Modification, 7(2), 183-196. 
Horner, R. H., Carr, E. G., Halle, J., McGee, G., Odom, S., \& Wolery, M. (2005). The use of single-subject research to identify evidence-based practice in special education. Exceptional Children, 71(2), 165-179.

Kanfer, F. H. (1970). Self-monitoring: Methodological limitations and clinical applications. Journal of Consulting and Clinical Psychology, 35,145-152.

Kauffman, J. M. (2005). How we prevent the prevention of emotional and behavioral disorders. Exceptional Children, 65(4), 448-468.

Kanfer, F. H., \& Karoly, P. (1972). Self-control: A behavioristic excursion into the lion's den. Behavior Therapy, 3, 398-416.

Kauffman, J. M., Bantz, J., \& McCullough, J. (2002). Separate and better: A special public school class for students with emotional and behavioral disorders. Exceptionality, 10(3), 149-170.

Kazdin, A. E. (1982). Single-case research designs: Methods for clinical and applied settings. New York, NY: Oxford University Press.

Kennedy, C. H. (2005). Single-case designs for educational research. Boston, MA: Allyn \& Bacon.

Kern, L. \& Dunlap, G. (1994). Use of a classwide self-management program to improve the behavior of students with emotional and behavioral disorders. Education and Treatment of Children, 17(4), 445-459

King-Sears, M. E., \& Bonfils, K. A. (1999). Self-management instruction for middle school students with LD and ED. Intervention in School and Clinic, 35(2), 96-107.

Kirby, K. C., Fowler, S. A., \& Baer, D. M. (1991). Reactivity in self-recording: Obtrusiveness of recording procedure and peer comments. Journal of Applied Behavior Analysis, 24(3), 487-498.

Kolb, L. (2008). Toys to tools: Connecting student cell phones to education. Eugene, OR: International Society for Technology in Education.

Korotitsch, W. J. \& Nelson-Gray, R. O. (1999). An overview of self-monitoring research in assessment and treatment. Psychology Assessment, 11(4), 415-425. 
Lenhart, A. (2009). Teens and Mobile Phones Over the Past Five Years: Pew Internet Looks Back. Pew Research Center's Internet \& American Life Project, Washington, DC.

Lipinski, D. P., Black, J. L., Nelson, R. O., \& Ciminero, A. R. (1975). Influence of motivational variables on the reactivity and reliability of self-recording. Journal of Consulting and Clinical Psychology, 43(5), 637-646.

Lloyd, J. W., Hallahan, D. P, Kosiewicz, M. M., \& Kneedler, R. D. (1982). Reactive effects of self-assessment and self-recording on attention to task and academic productivity. Learning Disability Quarterly, 5(3), 216-227.

Mahoney, M. J., \& Thoresen, C. E. (1972). Behavioral self-control: Power to the person. Educational Researcher, 1(10), 5-7.

Mathes, M., \& Bender, W. (1997). The effects of self-monitoring on children with attentiondeficit/hyperactivity disorder who are receiving pharmacological interventions. Remedial \& Special Education, 18(2), 121-128.

Mayer, M., Lochman, J., \& Van Acker, R. (2005). Introduction to the special issue: Cognitivebehavioral interventions with students with EBD. Behavioral Disorders, 30(3), 197-212.

McDougall, D. (1998). Research on self-management techniques used by students with disabilities in general education settings: A descriptive review. Remedial and Special Education, 19(5), 310-320.

McDougall, D. \& Brady, M. P. (1995). Using audio-cued self-monitoring for students with severe behavior disorders. The Journal of Educational Research, 88(5), 309-317.

McQuillan, K., \& DuPaul, G. J. (1996). Classroom performance of students with serious emotional disturbance: A comparative study of evaluation methods for behavior management. Journal of Emotional and Behavioral Disorders, 4(3).

McLaughlin, T. F. (1976). Self-control in the classroom. Review of Educational Research, 46(4), 631-663.

McNeal, T., \& van 't Hooft, M. (2006). Anywhere, anytime: Using mobile phones for learning. Journal of the Research Center for Educational Technology, 2(2), 24-31. 
Mooney, P., Ryan, J. B., Uhing, B. M., Reid, R., \& Epstein, M. H. (2005). A review of selfmanagement interventions targeting academic outcomes for students with emotional and behavioral disorders. Journal of Behavioral Education, 14(3), 203-221.

Nelson, R. O., \& Hayes, S. C. (1981). Theoretical explanations for reactivity in self-monitoring. Behavior Modification, 5(1), 3-14.

Ninness, H. A. C., Fuerst, J., Rutherford, R. D., \& Glenn, S. S. (1991). Effects of selfmanagement training and reinforcement on the transfer of improved conduct in the absence of supervision. Journal of Applied Behavior Analysis, 24(3), 499-508.

No Child Left Behind Act 2001, 20 U.S.C. $70 \S 6301$ et seq. (2002)

O’Leary, S. G. \& Dubey, D. R. (1979). Applications of self-control procedures by children: A review. Journal of Applied Behavior Analysis, 12(3), 449-465.

Peterson, L. D., Young, K. R., West, R. P., \& Peterson, M. H. (1999). Effects of student selfmanagement on generalization of student performance to regular classrooms. Education and Treatment of Children, 22(3), 357-372.

Polsgrove L., \& Smith, S. W. (2004). Informed practice in teaching self-control to children with emotional and behavioral disorders. In R. B. Rutherford, Jr., M. M. Quinn, \& S. R. Mathur (Eds.), Handbook of research in emotional and behavioral disorders (pp. 399425). New York, NY: Guilford Press.

Prater, M. A., Joy, R., Chilman, B., Temple, J., \& Miller, S. R. (1991). Self-monitoring of ontask behavior by adolescents with learning disabilities. Learning Disability Quarterly, 14(3), 164-177.

Rachlin, H. (1974) Self-control. Behaviorism, 2, 94-107.

Reid, R. (1996). Research in self-monitoring with students with learning disabilities: The present, the prospects, the pitfalls. Journal of Learning Disabilities, 29(3), 317-331.

Robinson, T. R., Smith, S. W., Miller, M. D., \& Brownell, M. T. (1999). Cognitive behavior modification of hyperactivity-impulsivity and aggression: A meta-analysis of schoolbased studies. Journal of Educational Psychology, 91(2), 195-203. 
Rock, M. L. (2005). Use of strategic self-monitoring to enhance academic engagement, productivity, and accuracy of students with and without exceptionalities. Journal of Positive Behavior Interventions, 7(1), 3-17.

Rock, E. E., Fessler, M. A., \& Church, R. P. (1997). The concomitance of learning disabilities and emotional/behavioral disorders: A conceptual model. Journal of Learning Disabilities, 30(3), 245-263.

Rooney, K. J., Hallahan, D. P., Lloyd, J. W. (1984). Self-recording of attention by learning disabled students in the regular classroom. Journal of Learning Disabilities, 17(6), 360364.

Rosenbaum, M. S. \& Drabman, R. S. (1979). Self-control training in the classroom: A review and critique. Journal of Applied Behavior Analysis, 12(3), 467-485.

Rosenberg, M. S., Sindelar, P. T., \& Hardman, M. L. (2004). Preparing highly qualified teachers for students with emotional or behavioral disorders: The impact of NCLB and IDEA. Behavioral Disorders, 29(3), 266-278.

Santogrossi, D. A., O’Leary, K. D., Romanczyk, R. G., \& Kaufman, K. F. (1973). Selfevaluation by adolescents in a psychiatric hospital school token program. Journal of Applied Behavior Analysis, 6(2), 277-287.

Shapiro, E. S., DuPaul, G. J., \& Bradley-Klug, K. L. (1998). Self-management as a strategy to improve the classroom behavior of adolescents with ADHD. Journal of Learning Disabilities, 31(6), 545-555.

Shimabukuro, S. M., Prater, M. A., Jenkins, A., \& Edelen-Smith, P. (1999). The effects of selfmonitoring of academic performance on students with learning disabilities and ADD/ADHD. Education and Treatment of Children, 22(4), 397-414.

Smith, D., \& Young, R. (1992). The effect of a self-management procedure on the classroom and academic behavior of students with mild handicaps. School Psychology Review, 21(1), 59-74.

Snider, V. (1987). Use of self-monitoring of attention with LD students: Research and application. Learning Disability Quarterly, 10(2), 139-151.

Tawney, J. W. \& Gast, D. L. (1984). Single subject research in special education. Columbus, $\mathrm{OH}$ : Bell \& Howell. 
Truesdell, L. A., \& Abramson, T. (1992). Academic behavior and grades of mainstreamed students with mild disabilities. Exceptional Children, 58(5), 392-399.

U.S. Department of Education. (2010). Common Core of Data. Institute of Education Sciences, National Center for Education Statistics. Retrieved from http://nces.ed.gov/ccd/schoolsearch/

U.S. Department of Education, Office of Elementary and Secondary Education. (2002). No child left behind: A desktop reference. Washington, DC: Author

U.S. Office of Special Education Programs. (2004). Individuals with Disabilities Education Act (IDEA) data. Retrieved. from http://www.ideadata.org. Individuals with Disabilities Education Improvement Act,611, 619 (2004).

Wood, S. J., Murdock, J. Y., \& Cronin, M. E. (2002). Self-monitoring and at-risk middle school students. Behavior Modification, 26(5), 605-626.

Wood, S. J., Murdock, J. Y., Cronin, M. E., Dawson, N. M., \& Kirby, P. C. (1998). Effects of self-monitoring on on-task behaviors of at-risk middle school students. Journal of Behavioral Education, 8(2), 263-279.

Wolf, M. M. (1978). Social validity: The case for subjective measurement or how applied behavior analysis is finding its heart. Journal of Applied Behavior Analysis, 11(2), 203214.

Wolfe, L. H., Heron, T. E., \& Goddard, Y. L. (2000). Effects of self-monitoring on the on-task behavior and written language performance of elementary students with learning disabilities. Journal of Behavioral Education, 10(1), 49-73. 